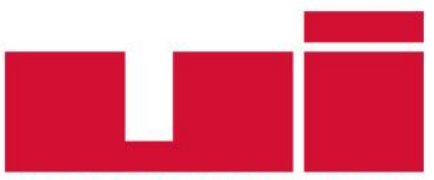

ULLUSLARARASIILIȘKiLER

Akademik Dergi

Yayın ilkeleri, izinler ve abonelik hakkında ayrıntılı bilgi:

E-mail: bilgi@uidergisi.com.tr

Web: www.uidergisi.com.tr

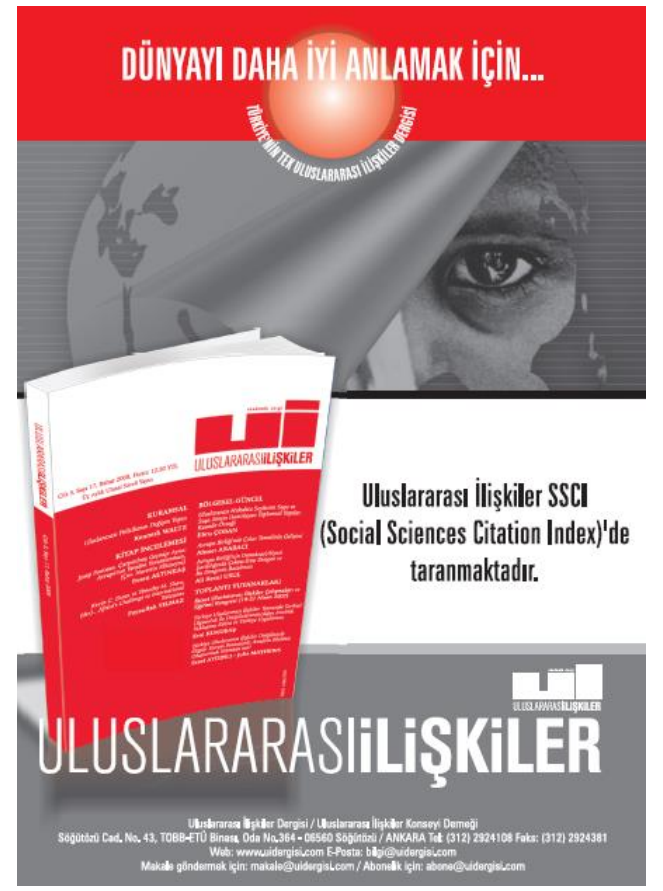

Güvenliksiz, Kalkınma, Kalkınmasız Güvenlik Mümkün mü? Güvenlik-Kalkınma Ilişkisinin Dönüşüm Süreci ve Farklı Yaklaşımlarla Kavramsallaştırılması

\author{
Arda BÍLGEN* \\ * Doktora Öğrencisi, Kalkınma Araştırmaları Merkezi (ZEF), \\ Bonn Üniversitesi
}

Bu makaleye atıf için: Bilgen, Arda, "Güvenliksiz Kalkınma, Kalkınmasız Güvenlik Mümkün mü? Güvenlik-Kalkınma İlişkisinin Dönüşüm Süreci ve Farklı Yaklaşımlarla Kavramsallaştırılması", Uluslararası İlişkiler, Cilt 14, Sayı 55, 2017, s. 19-40.

Bu makalenin tüm hakları Uluslararası İlişkiler Konseyi Derneği'ne aittir. Önceden yazılı izin alınmadan hiç bir iletişim, kopyalama ya da yayın sistemi kullanılarak yeniden yayımlanamaz, çoğaltılamaz, dağıtılamaz, satılamaz veya herhangi bir şekilde kamunun ücretli/ücretsiz kullanımına sunulamaz. Akademik ve haber amaçlı kısa alıntılar bu kuralın dışındadır.

Aksi belirtilmediği sürece Uluslararası Illişkiler'de yayınlanan yazılarda belirtilen fikirler yalnızca yazarına/yazarlarına aittir. UİK Derneğini, editörleri ve diğer yazarları bağlamaz. 


\title{
Güvenliksiz Kalkınma, Kalkınmasız Güvenlik Mümkün mü? Güvenlik-Kalkınma İlişkisinin Dönüşüm Süreci ve Farklı Yaklaşımlarla Kavramsallaştırılması
}

\author{
Arda BİLGEN \\ Doktora Öğrencisi, Kalkınma Araştırmaları Merkezi (ZEF), Bonn Üniversitesi, Almanya. \\ E-posta: ardabilgen@gmail.com
}

\section{ÖZET}

Küresel ölçekteki köklü değişim ve dönüşümlere rağmen, güvenlik ve kalkınma hem teorik hem pratik yönleriyle küresel siyaset gündemindeki kritik konumlarını korumuştur. Zamanla her iki alan içerisinde de değişim ve dönüşümler yaşanmış, ortaya çıkan insan güvenliği ve insani kalkınma gibi kavramlarla iki alan birbirini âdeta kapsayacak duruma gelmiştir. Bu çalışmanın amacı, güvenlik-kalkınma ilişkisinin nasıl insan paydasında kesişip bir güvenlik-kalkınma bağı altında kavramsallaştırıldığını genel hatlarıyla ve betimleyici bir şekilde tartışmaktır. Bu kapsamda öncelikle güvenlik ve kalkınmanın örtüşen karakteristik özellikleri, iki alan içerisindeki paradigma değişiklikleri ve iki alanın yakınlaşma süreci açıklanacak, ardından güvenlik-kalkınma ilişkisinin hangi şekillerde kavramsallaştırıldığı bu çabalara yöneltilen eleştirilerle birlikte tartışılacaktır.

Anahtar Kelimeler: Güvenlik, Kalkınma, İnsan Güvenliği, İnsani Kalkınma, Güvenlik-Kalkınma Bağı

\section{Is it Possible to Ensure Development without Security and Security without Development? Transformation of Security-Development Relationship and its Conceptualization with Different Approaches}

\begin{abstract}
Despite radical changes and transformations at global scale in the past decades, security and development have retained their critical positions in global political agenda with their theoretical and practical dimensions. Over time, two areas have also undergone significant changes and transformations and converged to each other, especially after the emergence of human security and human development. The aim of this study is to broadly describe and discuss how "human" has become the common denominator of security and development and in what ways two areas have been conceptualized under security-development nexus. In this regard, common characteristics of security and development, paradigm shifts in both areas, their convergence process, different ways as to how security-development relationship has been conceptualized, and critiques towards such attempts will be discussed.
\end{abstract}

Keywords: Security, Development, Human Security, Human Development, Security-Development Nexus 


\section{Giriş}

Güvenliğin ve kalkınmanın küresel ölçekteki değişim ve dönüşümlere rağmen teorik ve pratik boyutlarıyla yarım yüzyılı aşkın süredir küresel siyaset gündemindeki önemli yerlerini koruduğu söylenebilir. On yıllara yayılmış bu süre içinde güvenlik ve kalkınma kendi içlerinde paradigma değişiklikleri yaşamış, bu değişim süreçlerinin sonucu ortaya çıkan insan güvenliği ${ }^{1}$ ve insani kalkınma gibi kavramlarla beraber iki alan neredeyse birbirlerini kapsayacak derecede yakınlaşmıştır. Her ne kadar güvenliğin kalkınma boyutu, kalkınmanın da güvenlik boyutu olduğu fikri uzun yıllardır kabul görse de, 1990'lardan itibaren hem devletler hem de uluslararası kuruluşlar güvenlik ve kalkınmayı iki alanın birbirlerini karşılıklı olarak güçlendirdiği fikrinden yola çıkarak bir bağ (nexus) altında ele almaya başlamışlardır. Böylece güvenlik olmadan kalkınmanın, kalkınma olmadan da güvenliğin sağlanamayacağını vurgulayan görüş teorik düzeyde daha sık tartışılmaya başlanmış, pratik düzeyde de bu görüş doğrultusunda daha fazla politika üretilmiş ve uygulanmıştır. Buna rağmen güvenlik-kalkınma ilişkisinin nasıl yorumlanması gerektiği ve güvenlik-kalkınma bağının ne şekilde kavramsallaştırılabileceği sorularına tatmin edici cevaplar hâlâ bulunamamıştır.

$\mathrm{Bu}$ çalışmanın amacı güvenlik ve kalkınmanın zamanla nasıl insan paydasında kesişip güvenlikkalkınma bağı altında kavramsallaştırıldığını genel hatlarıyla ve betimleyici olarak açıklamaktır. Diğer bir ifadeyle bu çalışma yeni teorik argümanlar, kavramlar veya yaklaşımlar ortaya koyma amacı taşıyan bir çalışmadan ziyade ilgili Türkçe literatürde hemen hemen hiç değinilmemiş bir konuyu öne çıkartan ve literatürdeki kavramsal çalışma eksikliğini gidermeye katkıda bulunabilecek özgün bir çalışma, hatta bir literatür taraması şeklinde düşünülebilir. Bununla birlikte güvenlik ve kalkınma literatürlerini detaylı olarak tartışmak çalışmanın kapsamı dışındadır. Bunun yerine ilk olarak güvenlik ve kalkınmanın örtüşen karakteristik özelliklerinden bahsedilecektir. Takip eden iki bölümde güvenlik ve kalkınma alanlarında yaşanan paradigma değişiklikleri tartışılacaktır. Daha sonra iki alanın birbirine yakınlaşma süreci örneklerle zenginleştirilerek açıklanacaktır. Ardından güvenlik-kalkınma ilişkisinin ve bağının ne şekillerde kavramsallaştırıldığı aktarılacak ve güvenlik-kalkınma bağına getirilen temel eleştirilerden bahsedilecektir. Sonuç bölümünde ise çalışmanın kısa bir özeti verilecek ve genel bir değerlendirme yapılacaktır.

\section{Güvenlik ve Kalkınmanın Örtüşen Karakteristik Özellikleri}

İki alanda da yürütülen eleştirel çalışmaların ışığında güvenlik ve kalkınmanın en geniş anlamlarıyla iki farklı biçimde anlaşılabileceği söylenebilir. Güvenlikten başlamak gerekirse, birinci anlayışa göre güvenlik güç birikimiyle ilgilidir ve bir aktör özellikle de askerî olarak güçlendiği oranda güvenliğini sağlamış kabul edilmektedir. ${ }^{2}$ Bu bağlamda güvenlik bir meta olarak da anlaşılabilir. İkinci anlayışa

1 İlgili literatürde “insan güvenliği” terimiyle "insani güvenlik” terimi zaman zaman dönüşümlü olarak kullanılmaktadır. Örneğin, İstanbul'da her sene çeşitli kurum ve kuruluşların katkısıyla 2011'den beri düzenlenen "İstanbul Human Security Conference” Türkçe’ye resmî olarak “İstanbul İnsani Güvenlik Konferansı” şeklinde çevrilmiştir. Buna rağmen bu makalede hem Türkçe uluslararası ilişkiler literatürünün genelinde hem de Uluslararası İlişkiler Dergisi'nin eski sayılarında daha yaygın biçimde kullanılmasından dolayı kavramdan "insan güvenliği” şeklinde bahsedilecektir. Örnekler için bkz. A. Şevket Ovalı, "Ütopya ile Pratik Arasında: Uluslararası İlişkilerde İnsan Güvenliği Kavramsallaştırması”, Uluslararası İlişkiler, Cilt 3, No.10, 2006, s.3-52; Murat Necip Arman, "Avrupa Komşuluk Politikasında Sorunlu Alanlar: İnsan Güvenliği ve Komşuluk İlişkisi”, Uluslararası İlişkiler, Cilt 8, No.31, 2011, s.45-68.

2 Paul D. Williams, “Security Studies: An Introduction”, Paul D. Williams (der.), Security Studies: An Introduction, Oxon ve 
göreyse güvenlik, güç birikiminden ziyade Ken Booth tarafından bireyler ve gruplar olarak insanların özgürce yapmayı seçtikleri eylemleri yapmalarını engelleyen savaş, yoksulluk, adaletsizlik gibi yapısal veya bağlamsal biçimlerde görülebilen baskılardan kurtulmaları olarak tanımlanan "özgürleşmeyle" (emancipation) ilgilidir ve özgürleşme amacının bir aracı olarak düşünülebilir. ${ }^{3}$ Bu bağlamda güvenlik bir meta değil, farklı aktörler arasındaki ilişkiler bütünü olarak anlaşılabilir. ${ }^{4}$ Kalkınma ise her ne kadar yaygın olarak gelişme, büyüme, ilerleme, olumlu değişim, iyileşme gibi süreçlerle ilişkilendirilse ve hatta eş anlamlı olarak kullanılsa da, kalkınmanın ve kalkınma söyleminin doğuşunun izini sürmede öncülük yapan Cowen ve Shenton’a göre kalkınma öncelikle nesnel, bilinç dışı ve doğal yollarla kendiliğinden gerçekleşen "içkin” (immanent) bir süreç olarak adlandırılabilir. ${ }^{5}$ Büyüme, olgunlaşma, çürüme ve yenilenme gibi organik ve döngüsel değişim süreçleri böyle süreçler olarak kabul edilebilir. $\mathrm{Bu}$ döngüsel anlayış zamanla yerini çizgisel (linear) ve geri dönüşü olmayan (irreversible) bir süreç olarak düşünülen ve sınırsız iyileşme imkân ve potansiyelleriyle ilişkilendirilen ilerleme (progress) fikrine bırakmıştır. ${ }^{6}$ İlerlemenin doğal bir süreç olduğu fikrinin reddi ve ilerlemenin ve ilerlemenin yarattığı kaotik ortamın "uysallaştırılması" gerektiği fikrinin yaygınlaşmasıyla birlikte kalkınma bir aktör tarafından bilinçli, kasıtlı (intentional) ve kontrollü olarak zamanla değişim, ilerleme ve iyileşme yaratmak için uygulanan politika ve eylemler bütünü olarak da anlaşılmıştır. ${ }^{7}$ Her ne kadar bu farklı anlayışlar altında güvenliğin ve kalkınmanın farklı tanımları yapılabilse de, güvenlik ve kalkınmanın tam olarak ne olduğu sorusunun tüm zaman ve mekânlar için geçerli, herkes tarafından kabul görmüş bir cevabı yoktur ve iki kavrama yüklenen anlamlar bağlama göre değişebilmektedir. Bunun sebebi, iki kavramın da sadece genel hatlarıyla ve belirli durumlara ilişkin olarak tanımlanabilecek tartışmalı (contested) ve türetilmiş (derivative) kavramlar olmasıdır. ${ }^{8}$

Güvenlik ve kalkınmanın örtüştüğ̈ bir başka nokta, iki alanın sadece teorik düzeyde tartışılan konuları değil, aynı zamanda pratikte de insanların hayatlarını bire bir, hatta ölüm kalım derecesinde etkileyen konuları kapsamasıdır. Bu sebeple güvenlik de kalkınma da siyasi değerlerdir. Bu noktada siyasallıktan kasıt sadece güvenlik ve kalkınmaya ilişkin konuların günlük siyasette kullanılabilir olması değil, aynı zamanda Harold Lasswell'in siyaset tanımına uygun olarak "kimin, neyi, ne zaman ve nasıl elde edeceğini” de belirleyebilmesidir. ${ }^{9}$ Buna göre güvenlik ve kalkınmanın hem sınırlı kaynakların dağılımı konusunda belirleyici bir rol oynadıkları hem de söylem ve eylemleri meşrulaştırabilen araçlar oldukları söylenebilir. ${ }^{10} \mathrm{Bu}$ durumun oluşmasında hem güvenliğin hem de kalkınmanın normatif niteliğinin ve "mutlaka elde edilmesi gereken iyi şeyler oldukları" inancının yaygınlığının da etkili olduğu belirtilebilir. ${ }^{11}$

New York, Routledge, 2008, s.6.

3 Ken Booth, Theory of World Security, New York, Cambridge University Press, 2007, s.110.

4 Williams, "Security Studies", s.6.

5 Michael Cowen ve Robert Shenton, “The Invention of Development”, Jonathan Crush (der.), Power of Development, Londra, Routledge, 1995, s.26.

6 Knut G. Nustad, “The Ends of Development: Comments on an Obituary”, Forum for Development Studies, Cilt 24, No.1, 1997, s.158.

7 Cowen ve Shenton, “The Invention of Development”, s.26.

8 Björn Hettne, "Development and Security: Origins and Future", Security Dialogue, Cilt 41, No.1, 2010, s.33.

9 Williams, "Security Studies", s.1.

10 Hans Günter Brauch, "Güvenliğin Yeniden Kavramsallaştırılması: Barış, Güvenlik, Kalkınma ve Çevre Kavramsal Dörtlüsü”, Uluslararası İlişkiler, Cilt 5, No.18, 2008, s.2.

11 Marc von Boemcken ve Conrad Schetter, “Security: What is it? What does it do?", Friedrich-Ebert-Stiftung, Think Piece 09,2016, s.2. 
Güvenlik ve kalkınmanın örtüşen bir başka özelliği de daha önce belirtildiği gibi iki alanda da paradigma değişiklikleri yaşanmış olmasıdır. Takip eden iki bölümde önce güvenliğin, sonra da kalkınmanın zaman içinde geçirdiği değişimler ele alınacaktır.

\section{Devlet Odaklı Güvenlikten İnsan Odaklı Güvenliğe Geçiş}

Güvenliğin profesyonel ve akademik anlamda İkinci Dünya Savaşı sonrasında Anglo-Amerikan ülkelerinin öncülügünde incelenmeye başladığı söylenebilir. Bu dönemde güvenlik çalışmalarının uluslararası ilişkiler disiplininin bir alt disiplini olarak kabul edildiği, fakat özellikle Soğuk Savaş sonrasında zamanla bağımsız bir akademik alan haline geldiği bilinmektedir. ${ }^{12}$ Soğuk Savaş dönemindeki güvenlik anlayışı baskın olarak anarşik bir uluslararası sistemde ulus devletlerin bekaları için güçlerini ve egemenliklerini koruması veya artırması gerektiğini savunan realist teorilerin etkisinde şekillenmiştir. Buna göre dönemin iki süper gücü Amerika Birleşik Devletleri (ABD) ve Sovyet Sosyalist Cumhuriyetler Birliği’nin baskın olduğu iki kutuplu küresel sistemde bağımsız devletler en önemli aktörler olarak kabul edilirken, güvenlik anlayışı da askerî tehditlerin tespit ve bertaraf edilmesine, devlet güvenliğinin sağlanmasına ve statükonun korunmasına indirgenmiştir. ${ }^{13}$ Buna bağlı olarak bu dönemde millî güvenlik, silahlanma yarışı, kuvvetler dengesi, devletlerarası savaş, güvenlik ikilemi (security dilemma) ve özellikle 1955 sonrası dönemde nükleer silahlanma, caydırıcılık, sınırlı savaş gibi konular devletlerin gündeminde üst sıralarda yer almıştır. $^{14}$

Güvenliğin devlet güvenliğinden ibaret olmadığı düşüncesinin Soğuk Savaş’in sonuna doğru yaygınlaşmaya başladığı söylenebilir. Bunun sebeplerinden birisi, 1960’lardan itibaren iki kutuplu küresel sistemin yan ürünü olduğu düşünülen küçük çaplı çatışmaların Soğuk Savaş sonrasında da artarak ve biçim değiştirerek devam etmesidir. ${ }^{15} \mathrm{Bu}$ durum daha önce görece önemsiz görülen çatışmaların daha farklı boyutları olduğunu ve geleneksel uluslararası ilişkiler teorilerinin karmaşık çatışma dinamiklerini açıklamakta ve güvensizlikleri tespit etmede yetersiz kaldığını göstermiştir. Ayrıca bu teorilerin Soğuk Savaş’ın ne zaman ve nasıl bitebileceğini öngörememesi ve Soğuk Savaş sonrası ne gibi gelişmeler yaşanabileceğini açıklayamaması da bu değişimde etkili olmuştur. ${ }^{16}$ Bu bağlamda 1980'lerden itibaren güvenliğin sadece millî güvenlikle ve devlet güvenliğiyle ilgili değil, aynı zamanda askerî, siyasi, ekonomik, toplumsal ve çevresel sektörlerden etkilenen insan bütünlügüyle de ilgili olduğu vurgulanmış ve kişisel güvenlik, devlet güvenliği ve uluslararası güvenliğin bütüncül (holistic) bir yaklaşımla ele alınması gerektiği belirtilmiştir. ${ }^{17}$ Benzer şekilde 1990’larda güvenlik insanlar, etnik gruplar, yerel aktörler gibi devlet dışı aktörlerin de öneminin kavranması ve güvenlik tartışmalarına dâhil edilmesiyle "derinleşmiştir." Ayrıca güvenlik, devlet güvenliğine ek olarak çevre, gıda, sağlık, bilişim güvenliği gibi konuları; askerî tehditlere ek

12 Dubravka Zarkov ve Helen Hintjens, "Conflict, Peace, Security and Development: Theories and Methodologies”, Helen Hintjens ve Dubravka Zarkov (der.), Conflict, Peace, Security and Development: Theories and Methodologies, Londra ve New York, Routledge, 2015, s.6.

13 Williams, "Security Studies", s.3.

14 David A. Baldwin, "Security Studies and the End of the Cold War", World Politics, Cilt 48, No.1, 1996, s.122-123.

15 Jolle Demmers, “Theorising the Politics of Judgment”, Helen Hintjens ve Dubravka Zarkov (der.), Conflict, Peace, Security and Development: Theories and Methodologies, Londra ve New York, Routledge, 2015, s.236.

16 Baldwin, "Security Studies", s.118.

17 Barry Buzan, People, States, and Fear: The National Security Problem in International Relations, Brighton, Wheatsheaf, 1983. 
olarak da adaletsizlik, etnik çatışmalar, organize suçlar gibi tehditleri de kapsamına almasıyla "genişlemiştir." ${ }^{18}$ Güvenliğin bu yorumunun güvenlik çalışmalarını haddinden fazla genişlettiği, hemen her konuyu güvenliği tehdit eden bir mesele haline getirdiği, güvenlik alanının düşünsel tutarlılığını bozduğu ve hayati güvenlik sorunlarına çözüm üretilmesinin önünü tıkadığı iddialarıyla özellikle neorealist düşünürler tarafından eleştirildiği de not düşülmelidir. ${ }^{19}$ Buna rağmen 1990 'ların başından itibaren güvenliği sadece askerî tehditlerin tespiti ve bertaraf edilmesine ve savaşların önlenmesine indirgemeyen, aynı zamanda insanların mutluluk ve refahının sağlanması gerektiğini devlet güvenliğini tamamen geri plana itmeden vurgulayan insan merkezli "yeni güvenlik" anlayışı kabul görmeye başlamıştır. ${ }^{20}$ "Yeni güvenlik" herhangi bir felsefi, teorik veya metodolojik değişikliğe gitmeden sadece güvenliğin kapsamının genişletilmesi olarak değil, "güvenlik anlayış ve uygulamalarının merkezine insanın ihtiyaçlarını yerleştirmeyi hedefleyen topyekûn bir yenilenme girişimi” ${ }^{21}$ olarak anlaşılmalıdır. Bu bağlamda güvenlikleştirme (securitization) teorisi ve insan güvenliği kavramının ortaya çıkması ve yaygınlaşması güvenlik çalışmaları kapsamında en köklü iki dönüşüm olmuştur. ${ }^{22}$

Güvenlikleştirme teorisi 1990'ların ortalarında Ole Wæver tarafından uluslararası ilişkiler literatürüne sunulmuş ${ }^{23}$ ve daha sonra Kopenhag Ekolü bünyesindeki birçok farklı düşünür tarafından daha ayrıntılı olarak tartışılarak geliştirilmiştir. ${ }^{24}$ Sosyal inşacılık (social constructivism) yaklaşımı ve söz edimi (speech act) teorisi üzerine kurulan bu teoriye göre güvenlik bir söz edimidir ve güvenlik konuları kendiliğinden güvenlik sorunlarına veya tehditlere dönüşmemekte, aksine elitler tarafından söz edimleri aracılığıyla o şekilde inşa edilmekte ve güvenlikleştirilmektedir. ${ }^{25}$ Daha basit bir ifadeyle, bir konunun güvenlik sorunu olabilmesi için o konunun güvenlik sorunu olarak adlandırılması gerekmektedir. $\mathrm{Bu}$ bağlamda her konunun siyasileştirilmemiş (nonpoliticized), siyasileştirilmiş (politicized) ve güvenlikleştirilmiş (securitized) olarak adlandırılabilecek alanlar boyunca uzanan bir yelpaze üzerinde konumlandırıldığı düşünülürse, tehdit olarak sunulan ve güvenlikleştirilen bir konu diğer konular üzerinde öncelik kazanmaktadır. ${ }^{26}$ Böyle bir durumda iktidar sahipleri ve güvenlik eliti güvenlik sorunu olarak adlandırdıkları/inşa ettikleri tehditlere karşı alacakları kritik kararları ve kullanacakları olağanüstü araçları konunun önemli, acil, hayati, varoluşsal vb. olduğu algısına dayanarak meşru kılabilmektedir. ${ }^{27}$ Başarılı bir güvenlikleştirme için bir konunun bir referans nesnesini (referent object) tehdit ettiğini iddia eden söz ediminden-ya da güvenlikleştirici hamleden-daha

18 Bkz. Jessica Tuchman Mathews, "Redefining Security”, Foreign Affairs, Cilt 68, No.2, 1989, s.162-177; Keith Krause ve Michael C. Williams, "Broadening the Agenda of Security Studies: Politics and Methods", Mershon International Studies Review, Cilt 40, No.2, 1996, s.229-254.

19 Stephen M. Walt, “The Renaissance of Security Studies”, International Studies Quarterly, Cilt 35, No.2, 1991, s.213.

20 Pınar Bilgin, “Güvenlik Çalışmalarında Yeni Açılımlar: Yeni Güvenlik Çalışmaları”, Stratejik Araştırmalar, Cilt 8, No.14, 2010, s.72-77.

21 Ibid., s.79; Ayrica bkz. Ken Booth, "Security and Self: Reflections of a Fallen Realist”, Keith Krause ve Michael C. Williams (der.), Critical Security Studies: Concepts and Cases, Minneapolis, Minnesota University Press, 1997.

22 Zarkov ve Hintjens, "Conflict, Peace, Security and Development", s.7.

23 Ole Wæver, "Securitization and Desecuritization”, Ronnie D. Lipschutz (der.), On Security, New York, Columbia University Press, 1995.

24 Barry Buzan, Ole Wæver ve Jaap de Wilde, Security: A New Framework for Analysis, Boulder ve Londra, Lynne Rienner, 1998. Daha eleştirel bir yaklaşım için bkz. Thierry Balzacq, "The Three Faces of Securitization: Political Agency, Audience and Context”, European Journal of International Relations, Cilt 11, No.2, s.171-201.

25 Wæver, "Securitization and Desecuritization".

26 Buzan, Wæver ve Wilde, Security: A New Framework, s.23-24.

27 Ibid., s.24. 
fazlasına ihtiyaç vardır. Güvenlikleştirme, ancak hedef kitlenin (audience) de güvenlikleştirme hamlesi yapılan konuyu bir güvenlik sorunu olarak kabul etmesiyle, o sorunun varoluşsal bir tehdit olduğuna ikna olmasıyla ve akabinde alınacak olağanüstü önlemlere rıza göstermesiyle başarıya ulaşabilir. ${ }^{28}$ $\mathrm{Bu}$ bağlamda herhangi bir sorun nesnel olarak değil, sosyal olarak inşa edilerek ve "özneler arası” (intersubjective) bir süreç sonucu güvenlik sorunu olarak kabul edilmektedir. ${ }^{29}$ Ayrıca belirtilmelidir ki güvenlikleştirme her zaman ideal veya tercih edilen bir durum olarak görülmemektedir. Örneğin Kopenhag Ekolüne göre güvenlikleştirme kaçınılması gereken bir durumdur, zira güvenlikleştirme normalde siyasi alanda çözülebilecek bir soruna siyasi bir çözüm bulunamamasına işaret edebilmekte ve hesabı verilmeyen kaynak transferleri, orantısız şiddetin meşrulaşması, özgürlüklerin askıya alınması gibi anti-demokratik uygulamalara yol açabilmektedir. ${ }^{30} \mathrm{Bu}$ sebeple sorunların yukarıda bahsedilen yelpaze üzerindeki güvenlik alanından yeniden siyasileştirilmiş alana indirilmesi ve o alanda rutin kurallar çerçevesinde çözüm arayışları-ya da güvenlik-dışılaştırmak (desecuritization)-daha tercih edilen bir durumdur. Öte yandan Aberystwyth Ekolü sorunların güvenlik dışına çıkarılmasının bir çözüm getirmeyeceğini savunmakta ve bunun yerine "güvenliğin siyasiliğinin farkına varılması" gerektiğinin altını çizmektedir. ${ }^{31}$

İnsan güvenliği kavramının ise 1980 'lerin sonundan itibaren teorik düzeyde tartışılmaya başlandığı, özellikle 1992'de dönemin Birleşmiş Milletler (BM) Genel Sekreteri Boutros BoutrosGhali'nin açıladığı Barış için Gündem raporu ve Birleşmiş Milletler Kalkınma Programı'nın (UNDP) 1994 tarihli İnsani Kalkınma Raporu' yla devletlerin ve uluslararası kurumların gündemine girdiği söylenebilir. ${ }^{32}$ İnsan güvenliği fikrinin temelinde güvenliğin sadece sınırların ve toprakların dış tehditlere karşı korunmasına indirgenemeyeceği ve devletlerin güvenliğinin ve istikrarının yerine bireylerin korunması ve haklarına saygı gösterilmesi gerektiği anlayışı yatmaktadır. ${ }^{33}$ Buna göre insan güvenliği dar anlamıyla bireylerin terör, iç savaş gibi tehdit ve risklerden korunması anlamına gelmektedir. Geniş anlamıyla ise bireylerin sadece çatışmalardan değil, aynı zamanda doğal afetler, kıtlıklar gibi tehdit ve risklerden korunması anlamına gelmektedir. İnsani Kalkınma Raporu'nda insan güvenliği insanların “öncelikle açlık, salgın hastalıklar ve baskı gibi kronik tehditlere ve ikincil olarak evlerinde, işlerinde, topluluklarında günlük yaşantılarını etkileyebilecek ani ve zararlı aksamalara karşı güvende olması” ${ }^{34}$ şeklinde tanımlanmaktadır. Ayrıca, insan güvenliğine tehditler ekonomik, gıda, sağlık, çevre, kişisel, toplumsal, siyasi olmak üzere yedi boyutta ele alınmaktadır. ${ }^{35} \mathrm{Bu}$ anlamda insan güvenliği "korkudan ve yoksulluktan kurtulma” hak ve özgürlüklerine dayanan ve bireylerin kendi devletlerinden kaynaklanabilecek tehdit ve adaletsizlikleri de dikkate alan geniş bir çerçeve olarak değerlendirilebilir. Ayrıca insan güvenliğinin barışı sadece fiziksel şiddetin yokluğuna indirgeyen negatif barış anlayışının aksine

28 Ibid., s.25-26.

29 Ibid., s.30.

30 Wæver, "Securitization and Desecuritization".

31 Bilgin, "Güvenlik Çalışmalarında Yeni Açılımlar”, s.83.

32 Mark Duffield, "Human Security: Linking Development and Security in an Age of Terror”, Stephan Klingebiel (der.), New Interfaces Between Security and Development: Changing Concepts and Approaches, Bonn, Deutsches Institut für Entwicklungspolitik, 2006, s.22.

33 Lars Buur, Steffen Jensen ve Finn Stepputat, “The Security-Development Nexus”, Lars Buur, Steffen Jensen ve Finn Stepputat (der.), The Security-Development Nexus: Expressions of Sovereignty and Securitization in Southern Africa, Cape Town, HSRC Press, 2007, s.10.

34 UNDP, Human Development Report 1994, New York ve Oxford, Oxford University Press, 1994, s.23.

35 Ibid., s.24-25. 
örgütlü şiddete yol açan sebeplerin ve yapısal şiddetin ortadan kalktığı duruma işaret eden pozitif barış kavramıyla da örtüştüğü söylenebilir. ${ }^{36}$

İnsan güvenliği yaklaşımına yapılan eleştirilerin bazılarından bahsetmek gerekirse, yaklaşım yaygın olarak belirsiz ve geniş kapsamlı olduğu için eleştirilmektedir. Ayrıca, bu yaklaşımın insanların güvenliğini sağlama ve haklarını koruma sorumluluğunu yine devletlere yüklediği belirtilmektedir. ${ }^{37}$ Bir başka yaygın eleştiri de insan güvenliği yaklaşımının Küresel Güney’de güvensizliklerle mikro ve günlük düzeyde karşılaşan insanların gerçekliklerini dışlamasıdır, zira bu görüşe göre insan güvenliği yaygın biçimde uluslararası kalkınma kurumları ve aktörleri tarafından makro düzeyli ve tepeden inmeci bir politika yaklaşımıyla alanda faaliyete geçirilmektedir. ${ }^{38}$ İnsan güvenliği küresel düzeyde bir yönetimsellik (governmentality) ve düzenleme aracı işlevi gördüğü için de eleştirilmiştir. Buna göre insan güvenliği bireylerin korunması gereken varlıklar olduğu temsilini sürekli yeniden üretip bu şekilde devletlerin, devlet dışı aktörlerin ve uluslararası kuruluşların Küresel Güney üzerindeki kontrol edici pozisyonlarını güçlendirmektedir. ${ }^{39}$ Benzer eleştirilere rağmen insan güvenliğini sağlama amacının hâlâ birçok devlet ve uluslararası kuruluş için birincil derecede önem taşıdığı belirtilmelidir. ${ }^{40}$

\section{Ekonomik Gelişmeden İnsani Kalkınmaya Geçiş}

Kalkınmanın ağırlıklı olarak üretim, sanayileşme ve ekonomik büyüme odaklı bir anlayıştan bütüncül ve insan odaklı bir anlayışa evrildiği süreç ve sürece ilişkin detayları aktaran Tablo 1'de görülebileceği üzere güvenlik gibi kalkınma da bir akademik çalışma alanı ve siyasi proje olarak İkinci Dünya Savaşı sonrasında ortaya çıاkmıstır. Açmak gerekirse, dünya ilk defa 1949'da dönemin ABD Başkanı Harry S. Truman'ın yaptığı açılış konuşmasında mekânsal olarak bölünmüş ve ülkeler kalkınmışlık seviyelerine göre "müreffeh" ve "az gelişmiş" olarak sınıflandırılmıştır. ${ }^{41}$ Sömürgeci uygulamaları andıran bu sınıflamayla beraber Truman'ın aynı konuşmada sarf ettiği “ $[\mathrm{b}]$ ilimsel gelişmelerimizi ve endüstriyel ilerlememizi az gelişmiş bölgelerin gelişmesi için kullanabileceğimiz yeni ve cesur bir program başlatmalıyız." ${ }^{2}$ sözleri hem "kalkınma çağının” başladığını hem de Soğuk Savaş bağlamında ülkelerin “az gelişmişliğinin” sorunsallaştırıldığını göstermektedir.

36 Johan Galtung, "Violence, Peace, and Peace Research”, Journal of Peace Research, Cilt 6, No.3, 1969.

37 Zarkov ve Hintjens, "Conflict, Peace, Security and Development”, s.7.

38 Charlotte Lemanski, "Everyday Human (In)security: Rescaling for the Southern City”, Security Dialogue, Cilt 43, No.1, 2012, s.62.

39 Duffield, "Human Security", s.13.

40 Türkiye’de insan güvenliğinin göçler, azınlık hakları, sosyal dışlanma gibi boyutlarıyla birçok farklı sektörde incelendiği kapsamlı ve görece güncel bir çalışma için bkz. Alpaslan Özerdem ve Füsun Özerdem (der.), Human Security in Turkey: Challenges for the 21st Century, Oxon ve New York, Routledge, 2013.

41 Sylvia Chant ve Cathy McIlwaine, Geographies of Development in the $21^{\text {st }}$ Century: An Introduction to the Global South, Cheltenham, Edward Elgar, 2009, s.6.

42 Gilbert Rist, The History of Development: From Western Origins to Global Faith, Londra ve New York, Zed, 1997 , s.71. 
Tablo 1 Kalkınmanın Değişen Anlamları, Açıklamaları ve Hegemonları

\begin{tabular}{|c|c|c|c|c|}
\hline Dönem & Yaklaşım & $\begin{array}{l}\text { Kalkınmaya atfedilen } \\
\text { anlam }\end{array}$ & Açılklama & $\begin{array}{l}\text { Hegemon aktör veya } \\
\text { kavram }\end{array}$ \\
\hline $1850 s>$ & Sömürgecilik & $\begin{array}{l}\text { Kaynak yönetimi, vasilik } \\
\text { (trusteeship) }\end{array}$ & $\begin{array}{l}\text { Sömürgeci antropoloji, } \\
\text { Sosyal Darwinizm }\end{array}$ & Britanya İmparatorluğu \\
\hline $1870 s$ s & $\begin{array}{l}\text { Geç kalanlar } \\
\text { (Latecomers) }\end{array}$ & $\begin{array}{l}\text { Sanayileşme, } \\
\text { aynı düzeyi yakalamak }\end{array}$ & Klasik siyasal iktisat & $\begin{array}{l}\text { Geç kalanlar, } \\
\text { Sömürgecilik }\end{array}$ \\
\hline $1940 s$ > & $\begin{array}{l}\text { Kalkınma } \\
\text { iktisadı }\end{array}$ & $\begin{array}{l}\text { Sanayileşmeye dayalı } \\
\text { ekonomik büyüme }\end{array}$ & \multirow{2}{*}{$\begin{array}{l}\text { Büyüme teorisi, } \\
\text { Yapısal işlevselcilik }\end{array}$} & \multirow{2}{*}{$\mathrm{ABD}$} \\
\hline $1950 s>$ & $\begin{array}{l}\text { Modernleşme } \\
\text { teorileri }\end{array}$ & $\begin{array}{l}\text { Büyüme, siyasal ve sosyal } \\
\text { modernleşme }\end{array}$ & & \\
\hline $1960 s>$ & $\begin{array}{l}\text { Bağımlılık } \\
\text { teorileri }\end{array}$ & $\begin{array}{l}\text { Kendine yeterlilik } \\
\text { ve öz-merkezlilik } \\
\text { (autocentrism) yoluyla } \\
\text { sermaye birikimi }\end{array}$ & Neo-Marksizm & $\begin{array}{l}\text { Üçüncü Dünya } \\
\text { milliyetçiliği, } \\
\text { Bağlantısızlar Hareketi, } \\
\text { G77 }\end{array}$ \\
\hline $1970 s$ > & $\begin{array}{l}\text { Alternatif } \\
\text { kalkınma }\end{array}$ & $\begin{array}{l}\text { İnsani gelişim (Human } \\
\text { flourishing) }\end{array}$ & $\begin{array}{l}\text { Temel ihtiyaçlar } \\
\text { yaklaşımı, ekonomik } \\
\text { olarak ölçülemeyen } \\
\text { insan potansiyellerinin } \\
\text { değerlendirilmesi }\end{array}$ & $\begin{array}{l}\text { Feminizm, çevrecilik, } \\
\text { Gandicilik }\end{array}$ \\
\hline $1980 s>$ & $\begin{array}{l}\text { İnsani } \\
\text { kalkınma }\end{array}$ & $\begin{array}{l}\text { Kapasite oluşturma, } \\
\text { insanların seçeneklerinin } \\
\text { genişletilmesi }\end{array}$ & $\begin{array}{l}\text { Kabiliyetler, kalkınmacı } \\
\text { devlet }\end{array}$ & $\begin{array}{l}\text { Yükselen Asya ve Pasifik } \\
\text { ülkeleri, yükselen geniş } \\
\text { piyasalar }\end{array}$ \\
\hline $1980 s>$ & Neoliberalizm & $\begin{array}{l}\text { Yapısal reformlar } \\
\text { yoluyla ekonomik } \\
\text { büyüme, deregülasyon, } \\
\text { serbestleşme, } \\
\text { özelleştirme }\end{array}$ & $\begin{array}{l}\text { Neoklasik iktisat, } \\
\text { monetarizm }\end{array}$ & $\begin{array}{l}\text { Küreselleşme, finans } \\
\text { kapital, uluslararası } \\
\text { kalkınma ve finans } \\
\text { kuruluşları }\end{array}$ \\
\hline $1990 s>$ & $\begin{array}{l}\text { Kalkınma } \\
\text { sonrası (Post- } \\
\text { development) }\end{array}$ & $\begin{array}{l}\text { Otoriter ve teknokratik } \\
\text { mühendislik, yıkım, facia }\end{array}$ & $\begin{array}{l}\text { Modern sonrası (Post- } \\
\text { modern), sömürgeci } \\
\text { sonrası (post-colonialism), } \\
\text { yapısalcı sonrası (post- } \\
\text { structuralism) }\end{array}$ & $\begin{array}{l}\text { Hegemonik kalkınma } \\
\text { söylemi, kalkınma } \\
\text { fikrinin kendisi }\end{array}$ \\
\hline
\end{tabular}

Kaynak: Pieterse, Development Theory, s.7, 9.

1950’lere gelindiğinde sömürge devletlerin birer birer bağımsızlıklarını kazanmasıyla beraber bu yeni kurulan devletlerin ekonomilerinin ve "geleneksel" toplum yapılarının nasıl "modern" sosyal organizasyonlara dönüştürülmesi gerektiği sorusu özellikle Amerikan sosyal bilim çevrelerinde sorulmaya başlanmıştır. ${ }^{43} \mathrm{Bu}$ bağlamda ortaya çıkan modernleşme teorileri, Tablo 1'de de genel hatlarıyla belirtildiği gibi “az gelişmiş” toplumların Keynesyen bir anlayışışığında devlet müdahalesiyle ve "gelişmiş" Batı ülkelerinin geçmişte attığı adımları atarak ekonomik gelişme sağlayabileceğini ve demokratikleşebileceğini savunmuştur. Örneğin Rostow, referans noktası olarak, Sanayi Devrimi’ni alarak her geri kalmış toplumun (1) geleneksel toplum, (2) kalkışa hazırlık dönemindeki toplum, (3) kalkış aşamasındaki toplum, (4) olgunlaşma yolundaki toplum ve (5) kitle tüketim çağındaki toplum aşamalarından geçerek hızlıca ekonomik gelişme ve kalkınma sağlayabileceğini öne sürmüştür. ${ }^{44}$

43 Nathan Andrews ve Sylvia Bawa, "A Post-Development Hoax? (Re)-examining the Past, Present and Future of Development Studies", Third World Quarterly, Cilt 35, No.6, 2014, s.924.

44 Walt Whitman Rostow, Politics and the Stages of Growth, Cambridge, Cambridge University Press, 1971. 
Modernleşme teorileri ayrıca değişimi içeriden sağlayabilecek "modernleştirici elitlerin” yaratılmasına, tarımsal üretim ve verimin artırılmasına, büyük altyapı projelerinin yapılmasına ve Batı sermayesi ve teknolojisiyle sanayileşmeye büyük önem vermiştir. Gelgelelim kalkınma süreçlerinde kalkınmış olmakla Batılı olmanın âdeta eş değer görülmesi, Batılı sayılmayan toplumların "geri, ilkel, yerli" olarak temsil edilmesine ve Batılı toplumlardan hiyerarşik olarak daha alt seviyede oldukları fikrinin yaygınlaşmasına da sebep olmuştur. Kısacası, bu dönemde modernleşme teorilerinin öngördüğü kalkınma anlayışının ekonomik gelişme ve büyüme odaklı, pozitivist, homojenize edici, her zaman olumlu olduğu düşünülen, çizgisel, geri döndürülemez, evrimsel, teknokratik, etnosantrik, tek kültürlü ve normatif olduğu söylenebilir. ${ }^{45}$

1960’larda özellikle eski sömürge devletlerde yoksulluk ve eşitsizlik gibi ekonomik, sosyal ve siyasi sorunların daha da derinleşmesi modernleşme teorilerinin öngördüğü kalkınma anlayışına dair hayal kırıklığı yaratmıştır. Ayrıca, yine Tablo 1'de görülebileceği gibi, modernleşme teorilerinin eşitsizlikleri göz ardı etmesi, geleneksel-modern ikiliği, çizgiselliği ve etnosantrizmi Marksist paradigmanın temel varsayımları üzerinde yükselen Latin Amerika kökenli Bağımlılık Okulu tarafından eleştirilmiştir. ${ }^{46}$ Özetlemek gerekirse, bağımlılık teorileri Üçüncü Dünya veya Güney ülkelerinde yoksulluğun sürmesinin sebebi olarak gelişmiş ülkelerin kapitalist politikalarını işaret etmiştir. Ülkeleri merkez-çevre veya metropol-uydu ikiliği üzerinden sınıflayan bu yaklaşıma göre gelişmiş merkez ülkelerinin gelişmesi çevredeki Güney ülkelerini sömürmesiyle ve bu ülkeleri yoksul bırakmasıyla gerçekleşebilmektedir. Ülkeler resmî olarak bağımsızlıklarını kazansalar da sömürgeci devletler, çok uluslu şirketler, uluslararası finans kuruluşları neo-sömürgecilik vasıtasıyla sömürü sürecini sürdürmekte ve bu ülkelerin kalkınmalarına engel olmaktadır. Dolayısıyla bağımlılık teorisyenlerine göre kalkınmanın sağlanması için ülkelerin kendi kendine yetebilen öz-merkezli (autocentric) ekonomilere sahip olması ve yapısal eşitsizliklerle dolu kapitalist dünya sisteminden ayrılması hayati önem taşımaktadır. 1960'ların başında sömürgeciliğe, yayılmacılığa, dış müdahalelere karşı bir duruşla kalkınmayı sağlamayı amaçlayan ve çoğunlukla Afrika, Asya, Güney Amerika ve Ortadoğu ülkelerinin bir araya gelmesiyle Soğuk Savaş bağlamında üçüncü bir blok olarak ortaya çıan Bağlantısızlar Hareketi'nin (Non-Aligned Movement) veya yine 1960'ların başında BM bünyesinde gelişmekte olan ülkeler tarafından kendi ekonomik ve siyasi çıkarlarını daha iyi koruyabilmek adına oluşturulan G77 grubunun bu dönemin önemli oluşumları olduğu söylenebilir.

1980’lere gelindiğinde birkaç “kalkınmacı” Asya ülkesindeki başarılı uygulamalar haricinde devlet müdahalesiyle ekonomik kalkınma sağlamanın ve sosyal hayatı düzenlemenin verimsiz ve başarısız olduğu, dolayısıyla serbest piyasanın sorunlara çare olacağı fikirleri yaygınlaşmaya başlamıştır. ${ }^{47}$ Bununla beraber, 1982'de önce Meksika'nın, ardından birçok ülkenin dış borçlarını ödeyemeyecek hâle gelip moratoryum istemesi sonucu borç krizi çımıştır. Kredilerinin geri ödenmesini isteyen yabancı bankalar borçların yeniden yapılandırılması kararı almışlardır. Sorunu çözmek için bu ülkelerde Uluslararası Para Fonu (IMF) ve Dünya Bankası tarafından belirlenen ve şartlılık ilkelerine dayanan Yapısal Uyum Programları uygulanmaya başlanmıştır. Tablo l'de de özetlendiği gibi bu programların neoliberalizmin temel ilkeleri olan serbest piyasaları geliştirmek, devlet kurumlarını özelleştirmek, serbest ticareti geliştirmek, yabancı yatırımlara kapıları açmak ve devlet düzenlemelerini ve korumacılığını yok etmek gibi şartlardan oluştuğu söylenebilir. Bu düşünce ve uygulamalar bütünü Washington Konsensüsü olarak da isimlendirilmiştir. Bir başka

45 Emma Crewe ve Elizabeth Harrison, Whose Development?: An Ethnography of Aid, Londra ve New York, Zed, 1998.

46 Andrews ve Bawa, "A Post-Development Hoax?", s.925.

47 Ibid., s.42. 
deyişle, 1980’lerden itibaren neoliberalizm önce Kuzey ülkelerinde yayılmaya, daha sonra da Yapısal Uyum Programları vasıtasıyla Güney ülkelerine dayatılmaya başlamıştır. ${ }^{48}$ Neoliberalizmin özellikle liberalizm ve muhafazakârlık üzerinde yükselen, devletin ekonomide doğrudan üretici, dağıtıcı ve düzenleyici rolüne karşı çıkan, dönemin Birleşik Krallık Başbakanı Margaret Thatcher ve ABD Başkanı Ronald Reagan ile özdeşleşmiş “Yeni Sağ” döneminde küresel boyutta yükselişe geçtiği ve günümüzde küresel çapta en yaygın kalkınma yaklaşımı olduğu söylenebilir. Neoliberalizmin yükselişine paralel olarak 1980'lerde "sürdürülebilir kalkınma” kavramı da ortaya çıkmıştır. 1987'de BM’nin Brundtland Raporu olarak da bilinen Dünya Çevre ve Kalkınma Komisyonu Raporu'nda "gelecek kuşakların kendi ihtiyaçlarını karşılayabilme olanağından ödün vermeden bugünün ihtiyaçlarını karşılayabilecek kalkınma" olarak tanımlanan sürdürülebilir kalkınma bu tarihten itibaren yaygın şekilde kullanılmaya başlanmıştır. ${ }^{49}$ Her ne kadar sürdürülebilirlik modernleşme teorisinin evrimsel ve çizgisel kalkınma anlayışına bir tepki olarak ortaya çıksa da, kavramın zamanla çevre konularına ek olarak sosyal, ekonomik ve siyasi bağlamlarda kullanılarak muğlak bir hâle getirildiği de söylenebilir.

1990’lara gelindiğinde Soğuk Savaş’ın sona ermesi, küreselleşme süreci ve 1980’lerin kalkınma açısından özellikle Latin Amerika ve Sahraaltı Afrika ülkeleri için yine hayal kırıklığıyla sonuçlanması gibi faktörler sonucu kalkınma anlayışında ve politikalarında değişiklikler meydana gelmiştir. $\mathrm{Bu}$ dönemde kalkınma teori ve pratiği ve hegemonik kalkınma söylemi ciddi şekilde eleştirilmiş, hatta kalkınmanın bir yanılsamadan ${ }^{50}$ veya ölü bir fikirden ${ }^{51}$ öteye gitmediği dile getirilmiştir. Modern sonrası (post-modern) ve sömürgeci sonrası (post-colonial) teorilerden de beslenen kalkınma sonrası (post-development) yaklaşımlarıla kalkınmanın modernleşmeyle eş tutulmasına karşı çıkılmış ve kalkınmanın Güney'in gözünden değerlendirmesi amaçlanmıştır. ${ }^{52}$ Söylemlere ve güç ilişkilerine odaklanan bu yaklaşımlara göre kalkınmanın insanlar ve toplumlar arasındaki hiyerarşileri ve eşitsizlikleri ortadan kaldırmak yerine daha da perçinleyen bir işlevi olmuştur. Bir başka deyişle kalkınma zaman zaman Üçüncü Dünya şemsiyesi altında temsil edilen ülkelerdeki insanlar için zararlı sonuçlar doğurmuştur. Tablo l'de de belirtildiği gibi bu sebeplerle kalkınma tepeden inmeci, etnosantrik ve teknokratik olarak değerlendirilmiş, kalkınma adı altında insanların ve kültürlerin gelişmişliğinin istatistiklere ve soyut kavramlara indirgenmesi eleştirilmiştir. ${ }^{53} \mathrm{Bu}$ yaklaşımlar kalkınma kavramının topyekûn reddedilmesi veya doğal akışıyla tedavülden kalkması gerektiğini savunmuş, "kalkınma alternatifleri” yerine "kalkınmaya alternatifler" aranması gerektiğini vurgulamıştır. ${ }^{54}$

Ayrıca 1990'larda hem kalkınmanın aşırı derecede ekonomik gelişme odaklı olduğu hem de Yapısal Uyum Programlarının yoksullar üzerinde yıkıcı etkileri olduğu Dünya Bankası gibi aktörlerce bile fark edilmeye başlanmıştır. ${ }^{55}$ Böylece kalkınmanın ölçütü olarak sadece ekonomik göstergeleri dikkate alan yaklaşımlar yerine şeffaflık, demokratikleşme, insan haklarına saygı, katılımcılık, hesap verebilirlik, sürdürülebilirlik, iyi yönetişim gibi değerler üzerine kurulu yaklaşımlar ortaya çıkmış

48 Chant ve Mcllwaine, Geographies of Development, s.38.

49 The World Commission on Environment and Development, Our Common Future, Oxford, Oxford University Press, 1987, s.43.

50 Rist, The History of Development.

51 Wolfgang Sachs (der.), The Development Dictionary ( $2^{\text {nd }}$ ed.), Londra ve New York, Zed, 2010.

52 Chant ve Mcllwaine, Geographies of Development, s.48-49.

53 Arturo Escobar, Encountering Development: The Making and Unmaking of the Third World, Princeton, Princeton University Press, 1995, s.44.

54 Aram Ziai, ““Development”: Projects, Power, and a Poststructuralist Perspective”, Alternatives, Cilt 34, 2009 , s.184.

55 Michela Telatin, The Development-Security Nexus and Security Sector Reform, Doktora Tezi, Londra, University of Westminster, 2011, s.40. 
ve uluslararası kuruluşlar tarafından teşvik edilmiştir. ${ }^{56}$ Kalkınmanın böyle geniş bir perspektifle ele alınması sonucu 1990'da UNDP tarafindan ilk kez hazırlanan İnsani Kalkınma Raporu ile insani kalkınma kavramı ortaya çıkmıştır. "İnsani ilerlemeyi sadece ekonomik gelişmeyle ölçme hatasını sonlandırmayı" ${ }^{57}$ ve kalkınmanın merkezine yeniden insanı yerleştirmeyi amaçlayan bu yaklaşımla beraber kalkınmanın eğitim, sağlık, temel ihtiyaç ve özgürlükler gibi unsurlarla da ilgili olduğu anlayışı yaygınlaşmaya başlamıştır. Buna bağlı olarak 1990'da Pakistanlı ekonomist Mahbub ul Haq'ın Hint ekonomist Amartya Sen'in desteğiyle hazırladığı İnsani Kalkınma Endeksi'yle kalkınma (1) uzun ve sağlıklı bir yaşam, (2) bilgi ve eğitim, (3) yaşam standartları boyutlarıyla ve (a) ortalama yaşam süresi, (b) ortalama eğitim süresi, (c) beklenen eğitim süresi ve (d) kişi başına düşen millî gelir göstergeleriyle ölçülmeye başlanmış ve bu endeks ilerleyen yıllarda salt üretime ve millî gelir hesaplarına dayanan ölçümlere alternatif oluşturmuştur. ${ }^{58}$

Fark edilebileceği gibi güvenlik ve kalkınma insan paydasında kesişerek birbirlerine yakınlaşmış ve yirmi seneyi aşkın süredir insan güvenliği insani kalkınmanın, insani kalkınma da insan güvenliğinin ayrılmaz bir parçası haline gelmiştir. ${ }^{59}$ Bir başka deyişle, bir sonraki bölümde tartışılacağı gibi, zaman içinde güvenlik kalkınmalaşmış (developmentalization), kalkınma da güvenlikleştirilmiştir.

\section{Güvenliğin Kalkınmalaşması, Kalkınmanın Güvenlikleştirilmesi}

İnsan güvenliği ve insani kalkınma perspektifinden bakıldığında güvenliğin kalkınmalaşması, insanların hayatta kalmaları ve güvende olmaları için gerekli temel insani ihtiyaçların ve insan haklarının sağlanması konusunun kalkınmanın alanına girmesi anlamına gelmektedir. Kalkınmanın güvenlikleştirilmesiyse yoksul ülkelerdeki ekonomik eşitsizlikler, zayıf yönetişim, sosyal dışlanmışlık gibi unsurların ulusal ve uluslararası terörün, silahlı çatışmaların ve organize suçların doğrudan sebebi olarak görülmeye başlamasına işaret etmektedir. ${ }^{60}$ Bir not düşmek gerekirse, her ne kadar kalkınmanın güvenlikleştirilmesi bu bağlamda bazı kalkınma sorun ve süreçlerinin elitler tarafından güvenlik sorunları olarak tanımlanıp farklı referans nesneleri (devlet, toplum, toplumsal kimlik vb.) için tehdit kaynağı olarak algılanmaları anlamında kullanılsa da, bu güvenlikleştirme girişiminin ne derece başarılı olduğu ve hedef kitle tarafından ne derece benimsenip meşru bulunduğunu tartışmak çalışmanın kapsamı dışındadır. Burada amaç, titiz bir söylem analizi ve referans nesnelerinin, güvenlikleştirici aktörlerin, hedef kitlenin ne ve kimler olduğunun iyi tanımlanmasını gerektiren bir güvenlikleştirme analizi yapmaktan ziyade iki alanın birbirlerine yakınlaşma sürecine ve yapılan güvenlikleştirme hamlesiyle aldıkları girift yapıya vurgu yapmaktır.

Güvenlik-kalkınma ilişkisinin bu denli derinleşmesi görece yeni bir durum olsa da, güvenlik ve kalkınmanın ilintili olduğu fikrinin daha eskiye dayandığı söylenebilir. Tarihten örneklerle açıklamak gerekirse, kalkınma fikrinin tohumlarının Avrupa'da endüstriyel kapitalizmin yarattı̆̆ı kaosu ıslah etmek ve hızlı şehirleşme, yoksulluk ve işsizliğin yarattığı toplumsal kargaşayı düzene sokmak üzere atıldığı, bu yüzden de güvenlik sağlama işlevi olduğu belirtilmektedir. ${ }^{61}$ Daha yakın tarihi incelemek gerekirse,

56 Chant ve McIlwaine, Geographies of Development, s.282.

57 UNDP, Human Development Report 1996, New York ve Oxford, Oxford University Press, 1996, s.iii.

58 UNDP, “Human Development Index (HDI)". http://hdr.undp.org/en/content/human-development-index-hdi (Erişim Tarihi 15 Mart 2017).

59 UNDP, Human Development Report 2014-Sustaining Human Progress: Reducing Vulnerabilities and Building Resilience, New York, UNDP, 2014, s.4.

60 Buur, Jensen ve Stepputat, “The Security-Development Nexus”, s.8-9.

61 Cowen ve Shenton, “The Invention of Development”, s.27. 
1944’te Bretton Woods kurumlarının, 1945'te BM’nin kuruluş amaçlarının başında bir yandan barış ve güvenlik sorunlarının, diğer yandan da sosyo-ekonomik kalkınma sorunlarının çözülmesi geldiği söylenebilir. Soğuk Savaş dönemine göz atılırsa, daha önce bahsedilen konuşmada dönemin ABD Başkanı Truman'ın “[d] ünyadaki insanların yarısından fazlası sefalete yaklaşan koşullarda yaşamakta. Gıdaları yetersiz, hastalıklardan ötürü mağdurlar. Ekonomik hayatları ilkel ve durağan. Yoksullukları hem onlar hem de dünyanın daha müreffeh alanları için bir engel ve tehdit teşkil etmekte." ${ }^{62}$ sözleri Soğuk Savaş’ın ilk yıllarından itibaren "az gelişmişliğin”, "gelişmiş” Batı́nın güvenliğini tehdit eden bir unsur olarak görüldüğ̈̈nü göstermektedir. Ayrıca, İkinci Dünya Savaşı sonrasında Avrupa’nın ekonomik kalkınmasını sağlamak için ABD tarafından uygulanan Marshall Planı da benzer kaygılarla uygulanmıştır. 1950'lerden başlayarak Üçüncü Dünya'ya ve daha sonra Küresel Güney’e yapılan Resmî Kalkınma Yardımlarının ve çeşitli dış yardımların da ekonomik gelişme teşvikiyle dost rejimleri destekleyip kendi safında tutma ve küresel düzeni muhafaza etme amaçları taşıdığı, bu yüzden de kalkınma odaklı olduğu kadar ulusal çıkarlar ve millî güvenlik kaygılarıyla da yapıldığı söylenebilir. ${ }^{63}$ 1960'larla 1980'ler arası incelendiğinde, sömürgeci devletlerin sömürgelerinden çekilme sürecinde türetilen ve son yıllarda yeniden gündeme gelen "kalpleri ve akılları kazanma" stratejilerinin bir ayaklanmayı bastırmak için silahlı mücadele kadar kalkınma faaliyetlerinin de önemli olduğu fikrine dayandığı söylenebilir. McCuen'in bu bağlamda "[b]ir hükümet sadece nüfusun yeniden düzenlenmesini sağlamakla değil, aynı zamanda bunu devam ettirecek ortamı sağlamakla yükümlüdür. $\mathrm{Bu}$ ortamı sağlamak için halkın refahını sağlayacak etkili bir yönetimin olması hayatidir." sözleri de bu savı desteklemektedir. ${ }^{64}$

1990’ların başında Soğuk Savaş’ın bitmesi ve güvenlik ve kalkınma alanlarında yaşanan paradigma değişiklikleriyle beraber güvenlik-kalkınma ilişkisi daha derin bir boyut kazanmıştır. $\mathrm{Bu}$ dönemde geleneksel olarak uluslararası ilişkiler ve güvenlik çalışmaları altında incelenen çatışma, savaş, savaşın etkileri gibi konular kalkınma söylem ve politikalarında daha yaygın olarak yer almaya başlamıştır. Benzer şekilde birçok devlet ve uluslararası kuruluş çatışma sonrası yeniden yapılandırma gibi konular üzerine politika üretirken güvenlik ve kalkınmanın entegre olarak düşünülmesi gerektiği fikrini savunmuştur. ${ }^{65}$ İnsan güvenliğiyle beraber barış misyonlarının kapsamı genişlemiş ve hukukun üstünlüğü, insan hakları gibi unsurlar çatışmalı toplumlarda güvenliği sağlamanın bir parçası olarak düşünülmeye başlanmıştır. 1999'dan beri Kosova'da faaliyet gösteren ve barışçıl ve normal yaşam şartları oluşturmak, demokratik ve otonom kurumların kurulmasına yardımcı olmak, kilit öneme sahip altyapıların yeniden inşasına destek vermek, insan haklarını korumak ve yaymak, sivil düzeni korumak gibi amaç ve sorumlulukları bulunan BM Kosova Geçici Yönetim Misyonu buna örnek olarak gösterilebilir. ${ }^{66}$ İnsani kalkınmayla beraber ise güvenlik sektörü reformu, silahsızlandırma ve savaş suçlularının topluma yeniden kazandırılması gibi konular çatışmalı toplumların kalkınmasında önemli unsurlar olarak görülmeye başlanmıştır. Hatta 2000 yılında belirlenen; (1) aşırı yoksulluk ve açlığın giderilmesi, (2) evrensel ilköğretimin gerçekleştirilmesi, (3) cinsiyet eşitliğinin sağlanması ve kadınların konumunun güçlendirilmesi, (4) çocuk ölümlerinin azaltılması, (5) anne sağlığının

62 Escobar, Encountering Development, s.3.

63 Jo Beall, Thomas Goodfellow ve James Putzel, "Introductory Article: On the Discourse of Terrorism, Security and Development”, Journal of International Development, Cilt 18, 2006, s.52.

64 John J. McCuen, The Art of Counter-Revolutionary War: The Strategy of Counterinsurgency, London, Faber, 1966, s.326.

65 David Chandler, “The Security-Development Nexus and the Rise of 'Anti-Foreign Policy”, Journal of International Relations and Development, Cilt, 10, 2007, s.362.

66 UN, "UNMIK Mandate”. http://www.un.org/en/peacekeeping/missions/unmik/mandate.shtml (Erişim Tarihi 15 Mart 2017). 
iyileştirilmesi, (6) HIV/AIDS, sıtma ve diğer hastalıklarla mücadele edilmesi, (7) çevresel sürdürülebilirliğin sağlanması, (8) kalkınma için küresel iş birliğinin geliştirilmesi, hedeflerinin 2015'e kadar gerçekleştirilmesini amaçlayan BM Binyıl Kalkınma Hedefleri ve 2015 sonrası 15 yıl için yine BM girişimiyle hazırlanan ve 17 sürdürülebilir kalkınma hedefinden oluşan 2030 Sürdürülebilir Kalkınma Gündemi de insan güvenliği ve insani kalkınma kavramları doğrultusunda tasarlanmıştır. Ayrıca güvenlik-kalkınma ilişkisinin bir bağ içerisinde kavramsallaştırılması gerektiği fikri bu dönemde ortaya çıkmış ve yaygınlaşmaya başlamıştır. ${ }^{67}$

2000'lere gelindiğinde, özellikle El-Kaide'nin 11 Eylül 2001'de ABD’ye karşı gerçekleştirdiği terör saldırısıyla beraber hem devletler hem de uluslararası kuruluşlar güvenlik ve kalkınmanın birbirlerine bağlı olduğu ve birbirlerini güçlendirdiği fikrini âdeta mutlak doğruymuşçasına kabul etmeye başlamıştır. ${ }^{68}$ Bu fikre göre uzun vadeli bir kalkınma süreci güvenliğin sağlanmasına, uzun süreli bir güvenlik hâli de sürdürülebilir bir kalkınmaya bağlıdır. Eski BM Genel Sekreteri Kofi Annan’ın bu konuda, “[g]iderek birbirine daha da bağlı hâle gelen dünyamızda, kalkınma, güvenlik ve insan hakları alanındaki gelişmeler el ele gitmelidir. Güvenliksiz kalkınma, kalkınmasız güvenlik olamaz." ${ }^{99}$ sözleri bu savı destekler niteliktedir. Buna göre devletlerin "az gelişmişliği," "kırılganlığı," "geri kalmışlığı" gibi faktörler çatışmaları körükleyerek, çatışmalar da kalkınma süreçlerini engelleyerek kısır döngüsel bir "çatışma tuzağı" (conflict trap) yaratmaktadır. Bu durum sadece söz konusu devletlerin güvenliğini değil, aynı zamanda barış ve refah içinde yaşayan devletlerin güvenliğine de doğrudan veya dolaylı tehdit yaratmaktadır. Yine Kofi Annan’ın “[i]nsan sefaletinin bugünkü manzarasını göz ardı etmek geçmişe kıyasla daha zor. Geçmişle günümüz arasındaki en önemli fark günümüzde kaosların sınırlarla zapt edilememesi. Geçmişin aksine bugün kaoslar mülteci dalgaları, terörizm ve yasa dışı uyuşturucu, silah, hatta insan kaçakçılığı şeklinde yayılma eğiliminde.”70 sözleri bu noktanın altını çizmektedir. Bir anlamda, özellikle de ABD tarafından başlatılan "Teröre Karşı Küresel Savaş” bağlamında keskinleşen "biz ve onlar" ikiliğinde "onlar" kategorisindeki devletlerin "geri kalmışlığının" "biz” kategorisindeki devletlerin güvenliğini tehdit ettiği anlayışı bu dönemde iyice yaygınlaşmıştır. Ayrıca, geleneksel olarak ekonomik ve sosyal kalkınmayı gerçekleştirmekle yükümlü kurumlar da ek olarak suçları önleme, çatışma çözümleri, toplum güvenliği gibi konularda çalışmaya başlamıştır. ${ }^{71}$

Bir sonraki bölümde güvenliğin kalkınmalaşması ve kalkınmanın güvenlikleştirilmesiyle beraber boyut değiştirdiği düşünülen güvenlik-kalkınma ilişkisinin ve bağının hangi şekillerde kavramsallaştırıldığından bahsedilecektir.

\section{Güvenlik-Kalkınma İlişkisinin ve Bağının Kavramsallaştırılması}

Güvenlik-kalkınma ilişkisinin ve bağının ne şekilde vücut bulduğu sorusu bugüne kadar farklı perspektiflerden yanıtlanmaya çalışılmıştır. Bu çalışmada geniş kapsamlı, açıklayıcı ve görece güncel olmalarından dolayı Spear ve Williams'ın güvenlik-kalkınma ilişkisinin, Stern ve Öjendal'ın ise güvenlik-kalkınma bağının hangi şekillerde kavramsallaştırılabileceğini tartıştığı çalışmalardan

67 Telatin, “The Development-Security Nexus”, s.55.

68 Buur, Jensen ve Stepputat, “The Security-Development Nexus”, s.9.

69 UN, "In Larger Freedom: Towards Development, Security and Human Rights For All”, Report of the Secretary-General, A/59/2005, New York, 21 Mart 2005, s.55.

70 Kofi Annan, "In Haiti for the Long Haul”, Wall Street Journal, 16 Mart 2004.

71 The World Bank, World Development Report 2011: Conflict, Security, and Development, Washington, DC, The World Bank, 2011. 
bahsedilecektir. ${ }^{72}$ Buna göre Spear ve Williams güvenlik-kalkınma ilişkisini (1) sıfır toplamlı, (2) artı toplamlı, (3) ayrı, (4) eş anlamlı, (5) ardışık, (6) hiyerarşik, (7) seçici olarak birbirlerini oluşturan ve (8) kendine özgü olarak incelenebileceğini belirtmektedir. ${ }^{73}$

$\mathrm{Bu}$ başlıkları daha detaylı incelemek ve örneklerle açıklamak gerekirse, güvenlik-kalkınma ilişkisinin sıfır toplamlı olarak kavramsallaştırılmasına göre güvenlik ve kalkınma "biri ya da diğeri” şeklinde ifade edilmektedir. Buna göre sınırlı kaynakların bir alana aktarılması diğer alanda başarı sağlanmasını engellemektedir. ${ }^{74}$ Çatışmaların çözümünde askerî yöntemlere ağırlık verilmesi ve kaynakların bu alanda kullanılması sonucu çatışmaların sosyo-ekonomik boyutların görmezden gelinmesi veya ikinci plana atılması bu duruma örnek gösterilebilir.

Güvenlik-kalkınma ilişkisinin artı toplamlı olarak kavramsallaştırılmasına göre güvenlik ve kalkınma birbirlerini karşılıklı olarak güçlendirmektedir. Bir alanda başarı sağlanması diğer alanda başarı sağlama ihtimalini artırmaktadır. ${ }^{75}$ Bir önceki örneğin aksine çatışmaların çözümünde bir yandan askerî yöntemler uygulanırken diğer yandan çatışmayı körükleyen sosyo-ekonomik sorunların kapsayıcı bir şekilde ele alınması ve iki alana da yeterli kaynak aktarılması bu duruma örnek gösterilebilir.

Güvenlik ve kalkınmanın tamamen ayrı olarak kavramsallaştırılmasına göre ise iki alan da hayati öneme sahiptir ama bu alanların ayrı oldukları ve güvenlik ve kalkınma sağlamak için farklı yöntemler uygulanması gerektiği kabul edilmelidir. ${ }^{76}$ Yukarıdaki örneklerden devam etmek gerekirse, çatışmaların çözümünde silahlı çatışmaların temel sebeplerinin kalkınma sorunları olmadığı, kalkınma sorunlarının da silahlı çatışmaları etkilemediğinin düşünülmesi ve iki alanda birbirlerinden bağımsız uygulamalara gidilmesi bu yaklaşıma örnek gösterilebilir.

Güvenlik ve kalkınmanın eş anlamlı olarak kavramsallaştırılmasına göre güvenlik ve kalkınma temelde aynı şeylerdir, zira iki alan da odaklandıkları referans nesnelerinin öncelikli değer ve amaçlarının gerçekleşmesini amaçlamaktadır. ${ }^{77} \mathrm{Bu}$ görüşün daha önce bahsedilen güvenliksiz kalkınma, kalkınmasız güvenlik olmayacağını vurgulayan görüşe yakın olduğu söylenebilir. Örnek vermek gerekirse, bu konuda eski ABD Savunma Bakanı ve eski Dünya Bankası Başkanı Robert McNamara “[g]üvenlik kalkınmadır. Kalkınma olmadan güvenlik olamaz. Kalkınmakta olan bir ülke aslında kalkınmıyorsa güvenli kalamaz. Güvenli kalamaz, çünkü ülkenin vatandaşları insan doğalarından feragat edemez." 78 şeklinde düşünmektedir. Ayrıca, Batı merkezli liberal müdahaleciliğin özellikle 1990'lardan sonra "radikalleşmesi” bağlamında Sörensen ve Söderbaum'un "güvenlik her yerde. Kalkınma güvenliktir, bir güvenlik stratejisidir, ya da biz o şekilde olduğuna inanmaya alıştık." tespiti iki alanın temelde eş anlamlı düşünülebileceğine işaret etmektedir. ${ }^{79}$

72 Maria Stern ve Joakim Öjendal, "Mapping the Security-Development Nexus: Conflict, Complexity, Cacophony, Convergence?”, Security Dialogue, Cilt 41, No.1, 2010, s.17-24; Joanna Spear ve Paul D. Williams, “Conceptualizing the Security-Development Relationship: An Overview of the Debate”, Joanna Spear ve Paul D. Williams (der.), Security and Development in Global Politics: A Critical Comparison, Washington, DC, Georgetown University Press, 2012, s.21.

73 Spear ve Williams, "Conceptualizing the Security-Development Relationship", s.21.

74 Ibid.

75 Ibid.

76 Ibid.

77 Ibid.

78 Robert S. McNamara, The Essence of Security: Reflections in Office, New York, Harper and Row, 1968, s.149.

79 Jens Stilhoff Sörensen ve Fredrik Söderbaum, "Introduction - The End of the Development-Security Nexus?", Development Dialogue, No.58, 2012, s.7-20. 
Güvenlik ve kalkınmanın ardışık olarak kavramsallaştırılmasına göre güvenlik ve kalkınma birbirlerinin ön koşuludur. Buna göre kalkınmanın sağlanması için güvenli bir ortam, güvenliğin sağlanması için de asgari düzeyde kalkınmış bir ortam gerekmektedir. ${ }^{80} \mathrm{Bu}$ konuda Mans, "güvenlik ve kalkınma ayrılamaz. Bir tarafta, güvenlik kalkınmanın ön koşuludur. Diğer tarafta, sürdürülebilir kalkınma çatışmaların sona ermesinin ön koşuludur. Ayrıca, ekonomik ve insani kalkınma ve işleyen devlet hizmetleri istikrarın uzun süre korunması için esastır.” noktasının altını çizmektedir. ${ }^{81}$ Bir çatışmanın çözümünde öncelikle askerî yöntemlere ağırlık verilip huzurlu bir ortam sağlandıktan sonra ekonomik yatırımlarla çatışmanın bitirilmeye çalışılması bu duruma örnek gösterilebilir. Eski Dünya Bankası Başkanı Robert B. Zoellick’in "kırılgan” devletlerde “önce çatışmadan barışa yumuşak geçiş yapıp istikrarı sağlamak, bu sayede de kalkınmayı on yıl boyunca ve daha uzun süre sağlayabilmek" adına güvenlik ve kalkınmanın bir araya getirilmesi gerektiği fikri de bu yaklaşıma örnek gösterilebilir. ${ }^{82}$

Güvenlik-kalkınmailişkisinin hiyerarşik olarak kavramsallaştırılmasına göre güvenliköncelikleri kalkınma projelerinin neler olması ve nasıl uygulanması gerektiğinin temelini oluşturmaktadır. $\mathrm{Bu}$ durumun aynı zamanda kalkınmanın Batı ülkelerinin barış ve istikrarını korumak için bir araç olduğu algısını güçlendirdiği söylenebilir. ${ }^{83}$ Daha önce bahsedildiği gibi Soğuk Savaş bağlamında devletlerin siyasi ve güvenlik çıkarları doğrultusunda yaptıkları dış yardımlar veya iç güvenlik kaygılarıyla yapılan kalkınma yatırımları bu konuda örnek gösterilebilir.

Güvenlikvekalkınmanınseçiciolarakbirbirlerinioluşturanalanlarolarakkavramsallaştırılmasına göre güvenlik ve kalkınma birbirine bağlıdır ama bu bağ karmaşık ve her bağlama ve her konuya göre değişebilen bir karakter sergilemektedir. ${ }^{84}$ Buna göre örneğin güvenlik ve kalkınmayı bir bağ içinde düşünmek bir çatışma çözümü vakasında olumlu sonuçlar verebilirken, bambaşka dinamiklerin olduğu bir başka çatışma çözümü vakasında ters tepip olumsuz sonuçlar verebilmektedir.

Son olarak, güvenlik-kalkınma ilişkisinin kendine özgü olarak kavramsallaştırılmasına göre güvenlik ve kalkınmanın ne anlama geldiğini tamamen bağlam tarafından belirlenmektedir. Dolayısıyla iki alan arasındaki ilişkinin anlamlı bir şekilde kavramsallaştırılması imkânsızdır. ${ }^{85}$ Buna göre çatışmaların çözümünde güvenliğin ve kalkınmanın aktörler ve referans nesneleri için ne anlam ifade ettiği ülkeden ülkeye, bir ülke içinde bölgeden bölgeye, bir bölge içinde kentten kente bile bağlama göre değişebilmekteyken iki alanı entegre bir bağ altında düşünmenin mümkün olamaması bu konuda örnek gösterilebilir.

Stern ve Öjendal ise güvenlik-kalkınma bağının (1) ereksel/teleolojik olarak, (2) genişleyen, derinleşen ve insanileşen, (3) kurulması imkânsız (impasse) olarak, (4) kalkınma sonrası ve güvenlik sonrası perspektifiyle, (5) bir yönetimsellik tekniği olarak ve (6) küreselleşmiş (globalized) olarak altı başlıkta incelenebileceğini belirtmektedir. ${ }^{86}$

$\mathrm{Bu}$ başlıkları daha detaylı incelemek gerekirse, güvenlik-kalkınma bağını ereksel/teleolojik olarak kavramsallaştıran yaklaşım devletlerin baş aktörler olduğu modernist anlayışa dayalıdır. Buna

80 Spear ve Williams, "Conceptualizing the Security-Development Relationship", s.21.

81 Uli Mans, "Failing Fragile States? Afghanistan: Six Dilemmas for Dutch Foreign, Development and Defence Policy", Paul Hoebink (der.), The Netherlands Yearbook on International Cooperation, Assen, Royal Van Gorcum, 2007, s.66.

82 Robert B. Zoellick, "Fragile States: Securing Development", Survival, Cilt 50, No.6, 2008, s.69.

83 Spear ve Williams, "Conceptualizing the Security-Development Relationship", s.21.

84 Ibid.

85 Ibid.

86 Stern ve Öjendal, "Mapping the Security-Development Nexus", s.9. 
göre güvenlik ve kalkınma, devlet veya bölge gibi coğrafi olarak belirli bir alanın güvenliği ve kalkınması olarak düşünülmektedir. ${ }^{87}$ Güvenlik ve kalkınmanın sağlanması, ilerleme ve modernleşme sürecinin başarıyla yürütülmesine bağlıdır. Aynı şekilde güvenliğin sağlanması kalkınmaya, kalkınmanın sağlanması da güvenliğe bağlıdır. Örneğin bu yaklaşımda ekonomik gelişme, demokratikleşme, sosyal hizmetlerin verilmesi gibi kalkınma unsurlarının sağlanması sınırları içerisinde belirli oranda kontrol sağlayabilen ve meşru bir devletin varlığına, böyle bir devletin varlığı da kalkınma unsurlarının asgari düzeyde sağlanmış olmasına bağlıdır. ${ }^{88}$

Güvenlik-kalkınma bağını genişleyen, derinleşen ve insanileşen şekilde kavramsallaştıran yaklaşım, yukarıdaki yaklaşımın aksine aktörlerin güvenlik ve kalkınma sağlaması için neyi, nasıl yapması gerektiğini önceden belirleyen deterministik ve normatif bir yaklaşım olmaktan uzaktır. ${ }^{89}$ Buna göre bu yaklaşımda güvenlik ve kalkınma çizgisel ve devlet odaklı olmaktan ziyade döngüsel ve insan odaklıdır; dezavantajlı gruplar, kültürler, çevre gibi faktörler dikkate alınmıştır. Bu şekliyle bu yaklaşımın insan güvenliği ve insani kalkınma paradigmalarına yakın olduğu söylenebilir. ${ }^{90}$

Güvenlik-kalkınma bağını kurulması imkânsız olarak kavramsallaştıran yaklaşıma göre hem güvenlik hem de kalkınma kendi içlerinde bazı çıkmazlar yaşadıkları, yanlış yorumlandıkları ve gerçek anlamda sağlanmaları imkânsız olduğu için böyle bir bağın kurulması gereksiz ve imkânsızdır. ${ }^{91} \mathrm{Bu}$ yaklaşıma göre birçok sebepten dolayı güvenlik ve kalkınma sağlama çabaları ters tepebilmektedir. Güvenlik uygulamaları daha fazla korkuya, şiddete ve güvensizliğe, kalkınma projeleriyse insanların daha da yoksullaşmasına sebep olabilmektedir. Hâl böyleyken güvenlik-kalkınma bağının kurulması insanların güvenlik ve kalkınmışlık seviyesini artırmak bir yana, bir zaman ve kaynak kaybı olarak değerlendirilmektedir. ${ }^{92}$

Güvenlik-kalkınma bağını güvenlik sonrası ve kalkınma sonrası perspektifiyle değerlendiren yaklaşım da yukarıdaki yaklaşımla benzerdir. Bu yaklaşım güvenlik-kalkınma bağını belirli gerçeklikler ve iktidar araçları üretmeye yarayan söylemsel pratikler olarak görme eğilimindedir. ${ }^{93}$ Buna göre güvenlik ve kalkınma uygulamaları eşitsizlikleri, adaletsizlikleri, şiddeti ve güvensizlikleri yeniden üretebilir. Ayrıca güvenlik ve kalkınma alanları hem kendi içlerinde hem de birbirleriyle çeliştiği için iki alanın bir bağ içinde ele alınması fikri eleştirilmeli ve reddedilmelidir. ${ }^{94}$

Daha önce bahsedildiği gibi güvenlik-kalkınma bağını güvenlik ve kalkınmanın birbirlerini güçlendirdiği biyopolitika araçları olarak gören yaklaşım da mevcuttur. Bu çalışmada detaylı olarak incelemek mümkün olmasa da, Michel Foucault ile beraber sosyal bilimlerde kullanımı yaygınlaşmaya başlayan biyopolitika kavramı hayatların nüfus düzeyinde düzenlenmesiyle ilgili olup doğum ve ölüm oranları, yaşlılık ve hastalıklarla ilgili istatistikler, demografik sorunlar, ortalama yaşam süresini uzatmaya yönelik çalışmalar, salgın hastalıkların kayıt ve kontrol altına alınması gibi pek çok konuyu kapsamaktadır. ${ }^{95}$ Güvenlik ve kalkınma uygulamaları çerçevesinde insanların refahını ve dirençliliğini

87 Ibid., s.17.

88 Ibid., s.18.

89 Ibid.

90 Ibid., s.9.

91 Ibid.

92 Ibid.

93 Ibid.

94 Ibid., s.20.

95 Michel Foucault, "Governmentality”, Graham Burchell, Colin Gordon ve Peter Miller (der.), The Foucault Effect: Studies in Governmentality, ABD, University of Chicago Press, 1991, s.100. 
artırmaya yönelik ulusal ve uluslararası siyasi, ekonomik ve sosyal müdahalelerin de biyopolitika kapsamında ele alınabileceği söylenebilir. ${ }^{96}$ Zira bu uygulamalar düzenleyici (regulatory) unsurlar bulundurmakta ve insanların ekonomik ve sosyal yaşantılarının nasıl destekleneceği, korunacağı, geliştirileceği ve şekillendirileceği konusunda belirleyici rol oynamaktadır. ${ }^{97}$ Ayrıca, devletleri, toplumları ve insanları "daha üst seviyelere taşıma” amaçlı kalkınma uygulamalarının insan hayatlarını "yaşamasına değer” veya "tehlikeli, yetersiz, işe yaramaz” olarak ayırdığı, topluma kimin dâhil edilip edilmeyeceğini belirlediği de söylenebilir. ${ }^{98} \mathrm{Bu}$ anlamda kalkınmanın özellikle Küresel Güney'de toplumların temel ekonomik ve sosyal ihtiyaçlarının temini açısından biyopolitik bir güvenlik mekanizması olduğu iddia edilmektedir..$^{99}$ Ayaklanmayı bastırma çalışmaları, dış ve insani yardımlar, iyi yönetişim ve "Teröre Karşı Küresel Savaş” böyle bir bağ altında incelenebilir. Bu bağlamda hem söylemsel hem de somut biçimde bir güvenlik-kalkınma bağı olduğunun kabul edilmesi, özünde siyasi bir soru(n) olan egemen bir gücün neye dayanarak başka bir gücü veya hayatları yönetebileceği sorusunun içini boşaltmakta ve siyasetsizleştirmektedir. ${ }^{100}$

Son olarak, güvenlik-kalkınma bağını küreselleşmiş olarak kavramsallaştıran yaklaşıma göre yaygın olarak küreselleşmeyle beraber sınırların öneminin kalmadığına inanılan günümüz dünyasında gerçeklikleri anlamak için dünyayı modernist bir perspektifle sosyal, siyasi, kültürel olarak birbirlerinden ayrılmış şekilde algılamaktan ziyade küresel biçimde algılamak gerekmektedir. ${ }^{101}$ Zira küreselleşmeyle beraber belirsizlikler, riskler, tehditler ve sorumluluklar da küreselleşmiştir ve bu sorunlara yerel, coğrafi bölgelere has çözümlerden ziyade küresel çözümler üretmek gerekmektedir. Bu noktadan yola çıkıldığında, güvenlik-kalkınma bağının iklim değişikliği, gıda krizleri, doğal afetler gibi birbirleriyle bağlantılı karmaşık küresel sorunları bütünsel olarak ele almak ve çözüm üretmek için işlevsel bir araç olduğu ileri sürülmektedir. ${ }^{102}$

Yukarıda tartışılan yaklaşımlardan bazıları birbirleriyle örtüşmekte ve birbirlerini tamamlamakta, bazılarıysa birbirlerinden tamamen ayrılmaktadır. Bu çeşitlilikten de anlaşılacağı gibi güvenlik-kalkınma ilişkisinin ve bağının nasıl olması gerektiği konusunda bir mutabakat yoktur; hatta bir sonraki bölümde bahsedileceği gibi güvenlik ve kalkınmanın bir bağ altında kavramsallaştırılması birçok açıdan eleştirilmektedir.

\section{Güvenlik-Kalkınma Bağına Yöneltilen Temel Eleştiriler}

Güvenlik-kalkınma bağına yöneltilen başlıca eleştirilere değinmek gerekirse, örneğin, güvenlik ve kalkınma kavramlarının esnekliklerinden dolayı kendi alanlarında bile tam olarak ne anlama geldikleri ve neleri kapsayıp kapsamadıkları üzerinde bir uzlaşma yokken bir güvenlik-kalkınma bağından söz etmenin tutarsiz olduğu dile getirilmektedir. Daha önce bahsedildiği gibi, güvenlik devlet güvenliğinden insan güvenliğine, çevre güvenliğinden sınır aşan suçlara uzanan geniş bir yelpazede anlaşılabilir. Benzer şekilde kalkınma da insan haklarından sürdürülebilir çevreye, ekonomik gelişmeden iyi

96 Mark Duffield, “The Liberal Way of Development and the Development-Security Impasse: Exploring the Global LifeChance Divide”, Security Dialogue, Cilt 41, No.1, 2010, s.18.

97 Ibid.

98 Jessie Hanna Clark, “My Life Is Like a Novel': Embodied Geographies of Security in Southeast Turkey”, Geopolitics, Cilt 18,2013, s.838.

99 Mark Duffield, “The Liberal Way of Development”, s.18.

100 Stern ve Öjendal, "Mapping the Security-Development Nexus”, s.20.

101 Ibid.

102 Ibid., s.21. 
yönetişime kadar geniş bir yelpazede anlaşılabilir. Güvenlik ve kalkınma teorisyenleri ve uzmanları kimi zaman aynı dili konuşup aynı konular üzerinde çalışsa da, sadece kendi alanlarına odaklanıp diğer sorunları göz ardı edebilmekte ve öncelikleri, çıkış noktaları, nihai istekleri ve yaklaşımları farklılık gösterebilmektedir. ${ }^{103}$ Ayrıca kalkınma daha uzun vadeli, en az iki nesil sürebilecek bir girişimken, güvenlik genellikle daha aciliyet gerektiren bir girişim dir. ${ }^{104} \mathrm{Bu}$ durumda neyin, ne ile, nasıl ve neden entegre edilebileceği sorusu meşru ve cevaplaması zor bir soru olarak ortaya çıkmaktadır. Bir başka deyişle böyle bir bağ apayrı fikir ve süreçler arasında kurulabilecek sonsuz sayıda bağlantı ve ilişkiyi bünyesinde barındırabilir. ${ }^{105}$ Hatta bu durum güvenlik-kalkınma bağına içine her türlü anlamın yüklenebileceği bir "boş gösteren” (empty signifier) işlevi de yükleyebilir. ${ }^{106}$

Güvenlik ve kalkınma girişimleri her zaman iyi niyetli ve hedef kitlesindeki hayatları iyileştiren girişimler olarak değerlendirilebilir. Buna rağmen, daha önce bahsedildiği gibi devletlerin, toplumların, bireylerin güvenliğini ve refahını sağlamak için yapılan müdahaleler daha fazla şiddet, korku ve güvensizlik yaratabilmekte ve bireylere, kültürlere, çevreye zarar verebilmektedir. Bu durum güvenlik ve kalkınmanın bir bağ içinde düşünülmesi için de geçerlidir. İktidar sahipleri tarafından tepeden inmeci bir şekilde kurulan bu bağ, güvenlik ve kalkınma sorunlarını farklı düzeylerde deneyimleyen bireylerin gerçeklikleriyle uyuşmayabilmekte ve bu bireyler için çelişkili sonuçlar doğurabilmektedir. ${ }^{107}$ $\mathrm{Bu}$ bağlamda güvenlik ve kalkınmanın kavramsal ve siyasi olarak birlikte düşünülmesiyle beraber devletlerin meşru, gayrimeşru ve ideolojik yollarla hayatları düzenleme ve kontrol etme derecesinin görülmediği kadar arttığı ve bu durumun insan hayatlarının tüm yönlerinin üretilmesinin, yeniden üretilmesinin ve kontrol altında tutulmasının önünü açtığı söylenebilir. ${ }^{108}$

Yukarıdaki noktayla ilintili olarak güvenlik-kalkınma bağına yapılan bir başka eleştiri de bu bağ sebebiyle kalkınmanın aşırı güvenlikleştirilmesi ihtimali ve hemen her konunun bir güvenlik meselesi haline gelebilmesi riskidir. Ayrıca bu bağ sebebiyle kalkınma gündeminin Batı ülkelerinin güvenlik endişelerinin ve askerî çıkarlarının gölgesinde kalma riski de vardır. Bu endişe yersiz değildir, zira güvenlik-kalkınma bağının uygulama alanları olarak genellikle Küresel Güney ülkeleri düşünülmektedir. Bu durumda hem daha fazla ilgi gösterilmesi gereken ülke ve bölgelerdeki sorunların görmezden gelinme riskinin hem de ülkeler arasındaki hiyerarşik ilişkilerin daha da derinleşme riskinin artabileceği belirtilmektedir. ${ }^{109}$

Güvenlik ve kalkınmanın bir bağ altında düşünülmesinin bir başka yansımasının da egemenlik anlayışının değişmesi olduğu söylenebilir. 2000’lerin başında BM ve Kanada’nın öncülügünde Uluslararası Müdahale ve Devlet Egemenliği Komisyonu (ICISS) kurulmuş ve bu komisyon 2001'de hazırladığı raporda devlet egemenliğinin yeniden tanımlanması gerektiğini vurgulamıştır. Buna göre devlet egemenliği bir devletin sınırları içerisinde yaşayan insanları korumakla yükümlü olması olarak tanımlanmış ve devletin bu yükümlülüğü yerine getiremediği durumlarda devlet egemenliğinin yerini "koruma sorumluluğunun" (Responsibility to Protect) alacağı belirtilmiştir. ${ }^{110}$ Bu kavram 2005 BM

103 Spear ve Williams, “Conceptualizing the Security-Development Relationship”, s.10.

104 Ibid., s.16.

105 Stern ve Öjendal, "Mapping the Security-Development Nexus”, s.11.

106 Chandler, “The Security-Development Nexus”, s.367.

107 Camilla Orjuela, "The Bullet in the Living Room: Linking Security and Development in a Colombo Neighbourhood”, Security Dialogue, Cilt 41, No.1, 2010, s.103.

108 Clark, “"My Life Is Like a Novel”, s.837.

109 Simon Reid-Henry, "Spaces of Security and Development: An Alternative Mapping of the Security-Development Nexus”, Security Dialogue, Cilt 42, No.1, 2011, s.97.

110 Demmers, “Theorising the Politics of Judgment”, s.238. 
Dünya Zirvesi’nde onaylanmış, 2009'da güçlendirilmiştir. Bir başka deyişle, güvenlik ve kalkınma alanlarında insanın referans nesnesi olarak kabul edilmesi, hukuk temelli (veya yoğun hukuki tartışmalara neden olan) insani müdahalelerin ahlak temelli koruma sorumluluğuna evrilmesine yardımcı olmuştur. ${ }^{111} \mathrm{Bu}$ durum elbette birçok eleştiriyi de beraberinde getirmiştir. Örneğin, egemenliğin bu şekilde tanımlanması "kırılgan" (fragile) veya "başarısız" (failed) olarak adlandırılan devletleri dönüştürme yolunda dışarıdan yapılan askerî ve sivil müdahalelerin meşrulaştırılmasını kolaylaştırdığı için eleştirilmiştir. Bu bağlamda yapılan ve yapılacak olan müdahalelerin insani amaçlarla mı, hegemonik amaçlarla mı yapıldığı sorgulanmıştır. Ayrıca, bu egemenlik anlayışının güvenlik ve refahlarının sağlanması için müdahale edilmesi gerektiği düşünülen devletlerle müdahaleci ve "kurtarıcı" pozisyondaki devletler arasında yeni hiyerarşiler yarattı̆̆ı belirtilmiştir. ${ }^{12}$

Son olarak, bir başka eleştiriye göre güvenlik-kalkınma bağı sadece kısa vadede şiddeti önleyici bir rol oynamakta, uzun vadede pozitif bir barış ortamı sağlayamamaktadır. Açmak gerekirse, güvenlik ve kalkınma arasındaki korelasyonun pozitif değil negatif olduğu belirtilmektedir. ${ }^{113}$ Buna göre, "az gelişmişliğin" çatışmayı, çatışmanın da "az gelişmişliği” körüklemesi durumu geçerliyken, daha fazla kalkınmanın daha fazla güvenlik sağlaması, daha fazla güvenliğin de daha fazla kalkınma sağlaması durumu geçerli değildir. Bu sebeple de iki alanı bir bağ altında düşünmenin anlamsız olduğu fikri dile getirilmiştir. ${ }^{114}$

\section{Sonuç}

$\mathrm{Bu}$ çalışmada güvenlik ve kalkınmanın zamanla nasıl insan paydasında kesişip güvenlik-kalkınma bağı altında kavramsallaştırıldığı genel hatlarıyla ve betimleyici olarak açıklanmaya çalışılmıştır. Buna göre her ne kadar güvenlik ve kalkınma ilk bakışta birbirinden tamamen bağımsız alanlar olarak düşünülse de, iki alanın örtüşen birçok karakteristik özelliği olduğunun altı çizilmiştir. Örtüşen özelliklerinin yanı sıra İkinci Dünya Savaşı́ndan bu yana küresel ölçekte yaşanan siyasi, ekonomik, sosyal ve kültürel değişim ve dönüşümler güvenlik ve kalkınma teorilerini ve pratiğini etkilemiş, iki alanda da paradigma değişiklikleri yaşanmasına yol açmıştır. Bu sürecin ürünü olarak ortaya çıkan insan güvenliği ve insani kalkınma kavramları ve bu kavramların odağında insanın bulunması, güvenliğin ve kalkınmanın düşünüldüğü gibi birbirlerinden bağımsız olmayıp aksine iki alanın birbirlerinin ayrılmaz parçaları olduğu fikrinin yaygınlaşmasını sağlamıştır. Güvenlik-kalkınma ilişkisinin bu şekilde daha farklı bir boyut alması sonucunda iki alanın birbirlerine karşılıklı olarak bağımlı olduğu varsayılmış ve iki alan bir bağ altında düşünülerek farklı biçimlerde kavramsallaştırılmıştır.

Güvenlik-kalkınma ilişkisini açıklamaya çalışan kavramsal çerçevelerin hangilerinin "iyi, doğru, tutarlı, açıklayıcı, işlevsel”, hangilerinin "kötü, yanlış, tutarsız, kafa karıştırıcı, işe yaramaz" olduğu sorusunun mutlak bir cevabı yoktur. Yine de, şayet böyle bir kavramsallaştırma girişiminde bulunulacaksa hatırlanması gereken bazı hususlara dikkat çekilebilir. Öncelikle, güvenlik de kalkınma da göreceli olarak algılanması gereken kavramlardır; mutlak güvenlik veya mutlak kalkınma gibi durumları elde etmek imkânsızdır. Güvenlik ve kalkınma aynı zamanda yapısal faktörler kadar bağlamsal faktörler tarafından şekillendirilen ve bağlama göre tanımlamalarında ve uygulamalarında

111 Duffield, "Human Security", s.22-23.

112 Demmers, “Theorising the Politics of Judgment”, s.238.

113 Lisa Denney, "Reducing Poverty with Teargas and Batons: The Security-Development Nexus in Sierra Leone", African Affairs, Cilt 110, No.439, 2011, s.290.

114 Ibid., s.291. 
değişiklik gösterebilen kavramlardır; birinin güvenliği bir başkasının güvensizliği, birinin kalkınması bir başkasının yıkımı olabilmektedir. Ayrıca, güvenliğin de kalkınmanın da siyasi doğası olduğu, her zaman "birileri ve bazı amaçlar için" olabileceği ve insan unsurunu (human agency), tartışmayı (debate), müzakereyi (deliberation) ve çekişmeyi (contestation) dışlayan siyasetsizleştirilmiş, apolitize yaklaşımların iki alanda da kısa vadede fayda getirse bile uzun vadeli, sürdürülebilir sonuçlar veremeyeceği hatırlanmalıdır. Bu üç nokta elbette güvenlik ve kalkınmanın kaynakları mobilize etme gücü olduğu ve iki alanda da ele alınan konuların insan hayatı açısından önemli olduğu olgularını değiştirmemektedir. Benzer şekilde bu üç nokta güvenlik ve kalkınma sorunlarıyla ilgili hiçbir şey yapılmaması gerektiğini, yapılsa da hiçbir şey değişmeyeceğini savunmamakta ve ilgisizliği ve siyasi hareketsizliği meşrulaştırmamaktadır.

Yukarıda vurgulananların ışığında güvenlik ve kalkınma arasında yaygın olarak kabul gören etkileşim ve ilişki, kendiliğinden oluşan, durağan ve tek yönlü dar bir bağ kapsamına hapsedilmemelidir. Güvenliğin kalkınma alanında, kalkınmanın da güvenlik alanında oynadığı rol iddia edildiği kadar etkili ve belirleyici olamayabilir. Özellikle böyle katı-ve kati-bir bağın kurulmasının güvenlik ve kalkınma aktörleri ve referans nesneleri açısından pratik faydalarına dair yeterli ampirik çalışma ve kanıt olmadığ 1 dikkate alındığında, böyle bir kavramsallaştırma girişiminin teorik ve pratik katkısının sınırlı olacağı değerlendirmesi yapılabilir. Bu yüzden güvenlik-kalkınma ilişkisini bu denli daraltılmış bir bağ altında kavramsallaştırmaktansa, teoride ve pratikte iki alanın birbirlerine bağlı olup olmaması gerektiği, birbirlerini güçlendirip güçlendirmediği, birbirlerini engelleyip engellemediği gibi noktaların bağlam tarafından belirlendiğini kabul eden daha esnek, dinamik ve geniş perspektifli bir kavramsallaştırma girişimi bu ilişkiyi anlamlandırmakta daha yararlı olabilir. Bu girişim, "kimin ve neyin güvenliği?” ve "kimin ve neyin kalkınması?" sorularına teorik ve ampirik bilgilerin ışı̆̆ında ve eleştirel ve analitik bir bakış açısıyla tatmin edici cevaplar verildikten sonra formüle edilebilecek ve "ne ile neyin bağı, nasıl bir bağ, ve neden bir bağ?" sorularına verilecek-ya da verilemeyecek-cevaplar çerçevesinde şekillenecek bir şema yardımıyla daha sağlam temellere oturtulabilir. Dolayısıyla, güvenliği kalkınmayı sağlamak için, kalkınmayı da güvenliği sağlamak için âdeta sihirli bir formül gibi düşünüp iki alan arasındaki ilişkiyi dar ve mutlak kavramsal kalıplara hapsetmektense, iki alanı da tamamlanması uzun zaman alan karmaşık bir bulmacanın herhangi iki parçası olarak düşünmek daha yapıcı ve gerçekçi bir tutum olacaktır. Bu bağlamda bu çalışmanın da güvenlik-kalkınma ilişkisinin karmaşıklığına ve çok boyutluluğuna dikkat çekmesi açısından ilgili literatüre katkı sağladığı düşünülmektedir. 


\section{Kaynakça}

Andrews, Nathan ve Sylvia Bawa. "A Post-Development Hoax? (Re)-examining the Past, Present and Future of Development Studies", Third World Quarterly, Cilt 35, No.6, 2014, s.922-935.

Annan, Kofi. “In Haiti for the Long Haul”, Wall Street Journal, 16 Mart 2004.

Arman, Murat Necip. "Avrupa Komşuluk Politikasında Sorunlu Alanlar: İnsan Güvenliği ve Komşuluk İlişkisi”, Uluslararası İlişkiler, Cilt 8, No.31, 2011, s.45-68.

Baldwin, David A. "Security Studies and the End of the Cold War", World Politics, Cilt 48, No.1, 1996, s.117-141.

Balzacq, Thierry. “The Three Faces of Securitization: Political Agency, Audience and Context”, European Journal of International Relations, Cilt 11, No.2, s.171-201.

Beall, Jo, Thomas Goodfellow ve James Putzel. "Introductory Article: On the Discourse of Terrorism, Security and Development", Journal of International Development, Cilt 18, 2006, s.51-67.

Bilgin, Pınar. "Güvenlik Çalışmalarında Yeni Açılımlar: Yeni Güvenlik Çalışmaları", Stratejik Araştırmalar, Cilt 8, No.14, 2010, s.69-96.

Booth, Ken. "Security and Self: Reflections of a Fallen Realist", Keith Krause ve Michael C. Williams (der.), Critical Security Studies: Concepts and Cases, Minneapolis, Minnesota University Press, 1997.

Booth, Ken. Theory of World Security, New York, Cambridge University Press, 2007.

Brauch, Hans Günter. "Güvenliğin Yeniden Kavramsallaştırılması: Barış, Güvenlik, Kalkınma ve Çevre Kavramsal Dörtlüsü”, Uluslararası İlişkiler, Cilt 5, No 18, 2008, s. 1-47.

Buur, Lars, Steffen Jensen ve Finn Stepputat. "The Security-Development Nexus", Lars Buur, Steffen Jensen ve Finn Stepputat (der.), The Security-Development Nexus: Expressions of Sovereignty and Securitization in Southern Africa, Cape Town, HSRC Press, 2007.

Buzan, Barry. People, States, and Fear: The National Security Problem in International Relations, Brighton, Wheatsheaf, 1983.

Buzan, Barry, Ole Wæver ve Jaap de Wilde. Security: A New Framework for Analysis, Boulder ve Londra, Lynne Rienner, 1998.

Chandler, David. "The Security-Development Nexus and the Rise of 'Anti-Foreign Policy", Journal of International Relations and Development, Cilt 10, 2007, s.362-386.

Chant, Sylvia ve Cathy McIlwaine. Geographies of Development in the $21^{\text {st }}$ Century: An Introduction to the Global South, Cheltenham, Edward Elgar, 2009.

Clark, Jessie Hanna. "My Life Is Like a Novel': Embodied Geographies of Security in Southeast Turkey”, Geopolitics, Cilt 18, 2013, s.835-855.

Cowen, Michael ve Robert Shenton. "The Invention of Development", Jonathan Crush (der.), Power of Development, Londra, Routledge, 1995.

Crewe, Emma ve Elizabeth Harrison. Whose Development?: An Ethnography of Aid, Londra ve New York, Zed, 1998.

Demmers, Jolle. "Theorising the Politics of Judgment", Helen Hintjens ve Dubravka Zarkov (der.), Conflict, Peace, Security and Development: Theories and Methodologies, Londra ve New York, Routledge, 2015.

Denney, Lisa. "Reducing Poverty with Teargas and Batons: The Security-Development Nexus in Sierra Leone", African Affairs, Cilt 110, No.439, 2011, s.275-294.

Duffield, Mark. "Human Security: Linking Development and Security in an Age of Terror", Stephan Klingebiel (der.), New Interfaces Between Security and Development: Changing Concepts and Approaches, Bonn, Deutsches Institut für Entwicklungspolitik, 2006.

Duffield, Mark. "The Liberal Way of Development and the Development-Security Impasse: Exploring the Global Life-Chance Divide", Security Dialogue, Cilt 41, No.1, 2010, s.53-76.

Escobar, Arturo. Encountering Development: The Making and Unmaking of the Third World, Princeton, Princeton University Press, 1995.

Foucault, Michel. "Governmentality", Graham Burchell, Colin Gordon ve Peter Miller (der.), The Foucault Effect: Studies in Governmentality, ABD, University of Chicago Press, 1991.

Galtung, Johan. "Violence, Peace, and Peace Research", Journal of Peace Research, Cilt 6, No.3, 1969, s.167-191.

Hettne, Björn. "Development and Security: Origins and Future”, Security Dialogue, Cilt 41, No.1, 2010, s.31-52.

Krause, Keith ve Michael C. Williams. "Broadening the Agenda of Security Studies: Politics and Methods", Mershon International Studies Review, Cilt 40, No.2, 1996, s.229-254.

Lemanski, Charlotte. "Everyday Human (In)security: Rescaling for the Southern City”, Security Dialogue, Cilt 43, No.1, 2012, s.61-78.

Mans, Uli. “Failing Fragile States? Afghanistan: Six Dilemmas for Dutch Foreign, Development and Defence Policy”, Paul Hoebink (der.), The Netherlands Yearbook on International Cooperation, Assen, Royal Van Gorcum, 2007, s.64-81. 
Mathews, Jessica Tuchman. "Redefining Security”, Foreign Affairs, Cilt 68, No.2, 1989, s.162-177.

McCuen, John J. The Art of Counter-Revolutionary War: The Strategy of Counterinsurgency, Londra, Faber, 1966.

McNamara, Robert S. The Essence of Security: Reflections in Office, New York, Harper and Row, 1968.

Nustad, Knut G. “The Ends of Development: Comments on an Obituary”, Forum for Development Studies, Cilt 24, No.1, 1997, s.155-166.

Orjuela, Camilla. "The Bullet in the Living Room: Linking Security and Development in a Colombo Neighbourhood”, Security Dialogue, Cilt 41, No.1, 2010, s.99-120.

Ovalı, A. Şevket. “Ütopya ile Pratik Arasında: Uluslararası İlişkilerde İnsan Güvenliği Kavramsallaştırması”, Uluslararası İlişkiler, Cilt 3, No.10, 2006, s.3-52

Özerdem, Alpaslan ve Füsun Özerdem (der.), Human Security in Turkey: Challenges for the 21st Century, Oxon ve New York, Routledge, 2013.

Pieterse, Jan Nederveen. Development Theory: Deconstructions/Reconstructions, Londra, Sage, 2001.

Reid-Henry, Simon. "Spaces of Security and Development: An Alternative Mapping of the Security-Development Nexus", Security Dialogue, Cilt 42, No.1, 2011, s.97-104.

Rist, Gilbert. The History of Development: From Western Origins to Global Faith, Londra ve New York, Zed, 1997.

Rostow, Walt Whitman. Politics and the Stages of Growth, Cambridge, Cambridge University Press, 1971.

Sachs, Wolfgang (der.). The Development Dictionary ( $2^{\text {nd }}$ ed. $)$, Londra ve New York, Zed, 2010.

Sörensen, Jens Stilhoff ve Fredrik Söderbaum. "Introduction - The End of the Development-Security Nexus?", Development Dialogue, No.58, 2012, s.7-20.

Spear, Joanna ve Paul D. Williams. "Conceptualizing the Security-Development Relationship: An Overview of the Debate”, Joanna Spear ve Paul D. Williams (der.), Security and Development in Global Politics: A Critical Comparison, Washington, DC, Georgetown University Press, 2012.

Stern, Maria ve Joakim Öjendal. "Mapping the Security-Development Nexus: Conflict, Complexity, Cacophony, Convergence?”, Security Dialogue, Cilt 41, No.1, 2010, s.5-29.

Telatin, Michela. The Development-Security Nexus and Security Sector Reform, Doktora Tezi, Londra, University of Westminster, 2011.

The World Bank. World Development Report 2011: Conflict, Security, and Development, Washington, DC, The World Bank, 2011.

The World Commission on Environment and Development. Our Common Future, Oxford, Oxford University Press, 1987.

UN. "In Larger Freedom: Towards Development, Security and Human Rights For All”, Report of the SecretaryGeneral, A/59/2005, New York, 21 Mart 2005.

UN. “UNMIK Mandate”. http://www.un.org/en/peacekeeping/missions/unmik/mandate.shtml (Erişim Tarihi 15 Mart 2017).

UNDP. “Human Development Index (HDI)”. http://hdr.undp.org/en/content/human-development-indexhdi (Erişim Tarihi 15 Mart 2017).

UNDP. Human Development Report 1994, New York ve Oxford, Oxford University Press, 1994.

UNDP. Human Development Report 1996, New York ve Oxford, Oxford University Press, 1996.

UNDP. Human Development Report 2014-Sustaining Human Progress: Reducing Vulnerabilities and Building Resilience, New York, UNDP, 2014.

von Boemcken, Marc ve Conrad Schetter. "Security: What is it? What does it do?”, Friedrich-Ebert-Stiftung, Think Piece 09, 2016.

Walt, Stephen M. “The Renaissance of Security Studies”, International Studies Quarterly, Cilt 35, No.2, 1991, s.211-239.

Wæver, Ole. "Securitization and Desecuritization”, Ronnie D. Lipschutz (der.), On Security, New York, Columbia University Press, 1995.

Williams, Paul D. “Security Studies: An Introduction”, Paul D. Williams (der.), Security Studies: An Introduction, Oxon ve New York, Routledge, 2008.

Zarkov, Dubravka ve Helen Hintjens. “Conflict, Peace, Security and Development: Theories and Methodologies”, Helen Hintjens ve Dubravka Zarkov (der.), Conflict, Peace, Security and Development: Theories and Methodologies, Londra ve New York, Routledge, 2015.

Ziai, Aram. "”Development”: Projects, Power, and a Poststructuralist Perspective”, Alternatives, Cilt 34, 2009, s.183-201.

Zoellick, Robert B. “Fragile States: Securing Development”, Survival, Cilt 50, No.6, 2008, s.67-84. 